\title{
EVALUATION OF ALTERNATIVES TO THE ONTARIO HYDRO METHOD AS A REFERENCE METHOD FOR CAMR
}

\author{
Final Report \\ (for the period March 1, 2006, through March 31, 2007) \\ Prepared for: \\ AAD Document Control \\ U.S. Department of Energy \\ National Energy Technology Laboratory \\ PO Box 10940, MS 921-107 \\ Pittsburgh, PA 15236-0940
}

Cooperative Agreement No. DE-FC26-98FT40321

Performance Monitor: Charles Miller

Prepared by:

Dennis L. Laudal

Energy \& Environmental Research Center University of North Dakota 15 North 23rd Street, Stop 9018 Grand Forks, ND 58202-9018 


\section{DOE DISCLAIMER}

This report was prepared as an account of work sponsored by an agency of the United States Government. Neither the United States Government, nor any agency thereof, nor any of their employees makes any warranty, express or implied, or assumes any legal liability or responsibility for the accuracy, completeness, or usefulness of any information, apparatus, product, or process disclosed or represents that its use would not infringe privately owned rights. Reference herein to any specific commercial product, process, or service by trade name, trademark, manufacturer, or otherwise does not necessarily constitute or imply its endorsement, recommendation, or favoring by the United States Government or any agency thereof. The views and opinions of authors expressed herein do not necessarily state or reflect those of the United States Government or any agency thereof.

This report is available to the public from the National Technical Information Service, U.S. Department of Commerce, 5285 Port Royal Road, Springfield, VA 22161; phone orders accepted at (703) 487-4650.

\section{EERC DISCLAIMER}

LEGAL NOTICE This research report was prepared by the Energy \& Environmental Research Center (EERC), an agency of the University of North Dakota, as an account of work sponsored by U.S. Department of Energy, Electric Power Research Institute, and Reliant Energy. Because of the research nature of the work performed, neither the EERC nor any of its employees makes any warranty, express or implied, or assumes any legal liability or responsibility for the accuracy, completeness, or usefulness of any information, apparatus, product, or process disclosed, or represents that its use would not infringe privately owned rights. Reference herein to any specific commercial product, process, or service by trade name, trademark, manufacturer, or otherwise does not necessarily constitute or imply its endorsement or recommendation by the EERC. 


\title{
EVALUATION OF ALTERNATIVES TO THE ONTARIO HYDRO METHOD AS A REFERENCE METHOD FOR CAMR
}

\begin{abstract}
In June 2005, the U.S. Environmental Protection Agency (EPA) finalized the Clean Air Mercury Rule (CAMR). As part of the rule, all coal-fired power plants will be required to do continuous mercury measurements. To complete the required relative accuracy test assessment (RATA), the only reference methods allowed are the wet-chemistry methods: the Ontario Hydro $(\mathrm{OH})$ mercury speciation method (ASTM International D6784-02) and EPA Method 29. Either method will be a challenge and expensive. It would be much more desirable to use an instrumental reference method (IRM) or use sorbent traps as a reference method so that the results can be obtained quickly and cheaply. This report presents the results from testing at Reliant Energy, Inc.'s, Portland Station. The project was designed to compare mercury concentrations measured using sorbent traps to those obtained using the $\mathrm{OH}$ method. The tests were done using a RATA scenario and at three different conditions. In addition, as part of the project, limited IRM testing was also completed. The results from the testing show that the sorbent traps compared very well with the $\mathrm{OH}$ method and, therefore, must be considered as a potential reference method.
\end{abstract}

Although the IRM testing using manual injection of elemental and oxidized mercury for dynamic spiking showed some promise, it was clear that additional testing was needed. However, this method of dynamic spiking may not be acceptable to EPA, as it does not consider vapor pressure curves for elemental mercury a National Institute of Standards Technologytraceable standard. 


\section{TABLE OF CONTENTS}

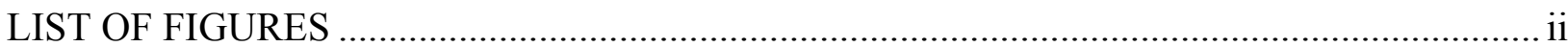

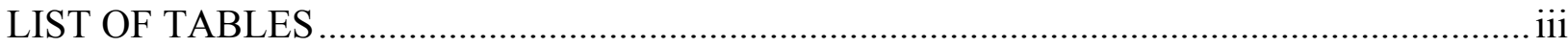

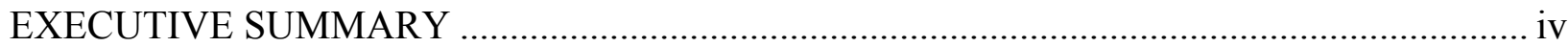

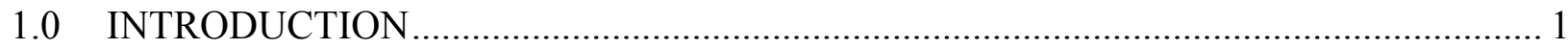

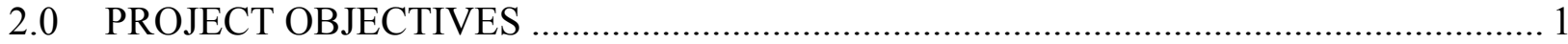

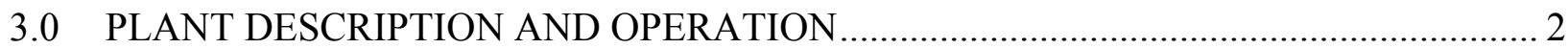

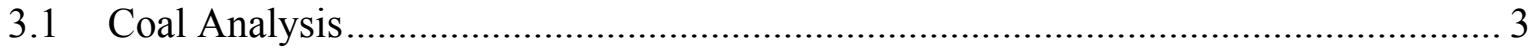

3.2 Plant Operation ……………………………….......................................... 3

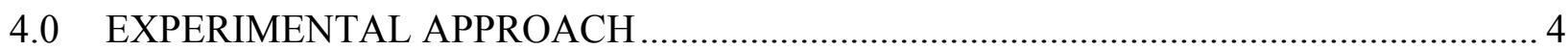

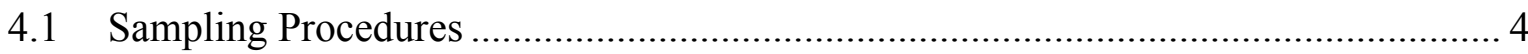

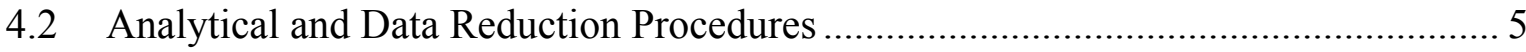

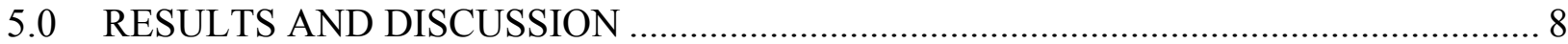

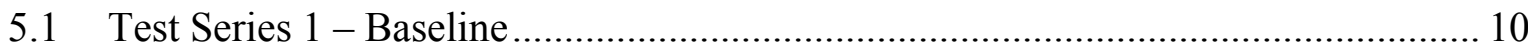

5.2 Test Series 2 - Midlevel Mercury Control ......................................................... 10

5.3 Test Series 3 - High-Level Mercury Control .............................................................. 11

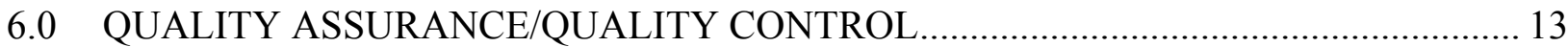

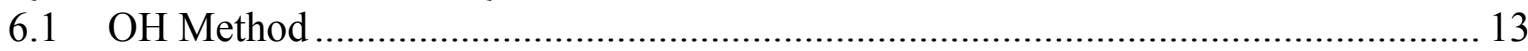

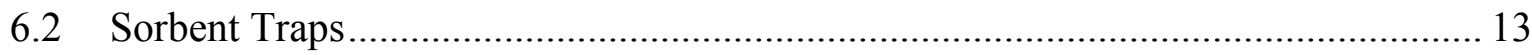

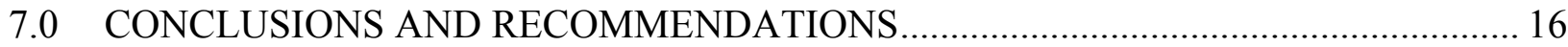

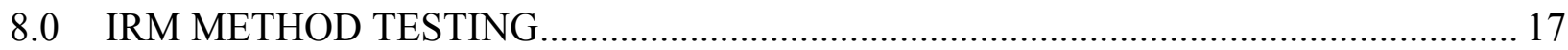

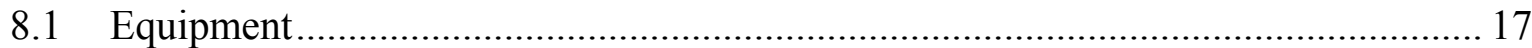

8.2 Method Viability Tests ................................................................................... 18

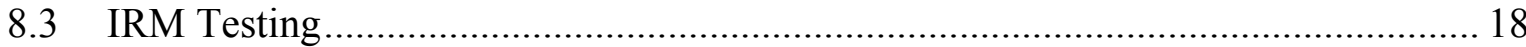

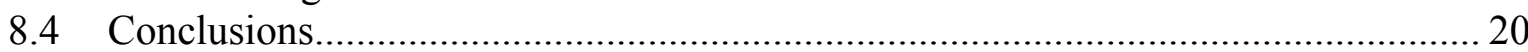

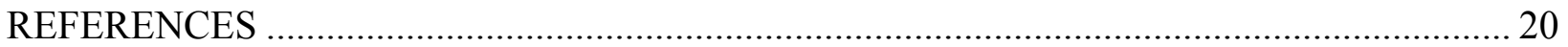




\section{LIST OF FIGURES}

1 Schematic of Reliant Energy's Portland Power Plant, Unit 1 ....................................... 2

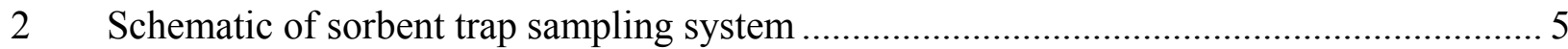

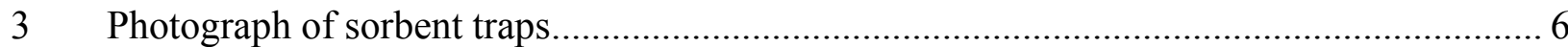

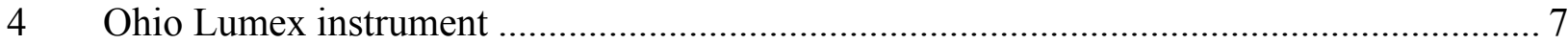

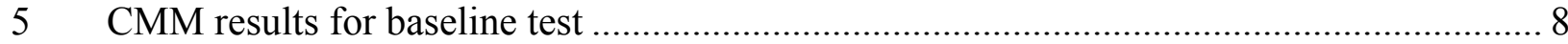

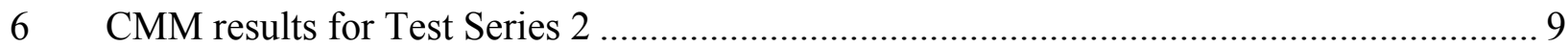

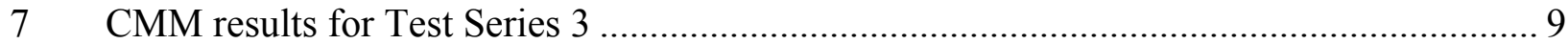

$8 \quad$ EERC oxidized mercury-spiking system ........................................................... 18

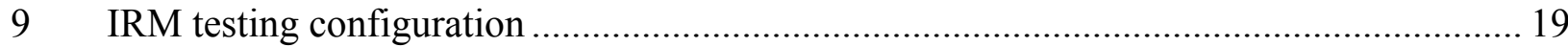




\section{LIST OF TABLES}

$1 \quad$ Typical Coal Analysis for the Portland Power Plant........................................................... 3

2 Average Plant Data for Test Series 1 ............................................................................. 3

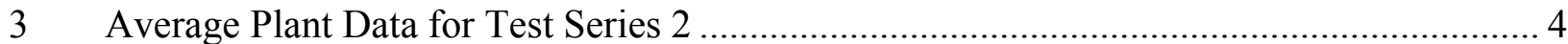

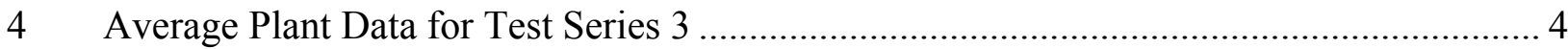

5 Mercury Measurement Comparisons at Reliant's Portland Station - Test Series 1 ............ 10

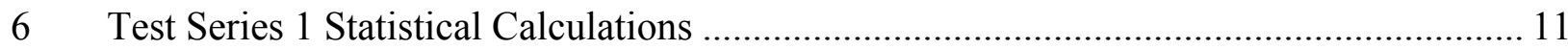

$7 \quad$ Test Series 1 Statistical Results for Each Mercury Measurement Method ........................... 11

8 Mercury Measurement Comparisons at Reliant's Portland Station - Test Series 2 ........... 11

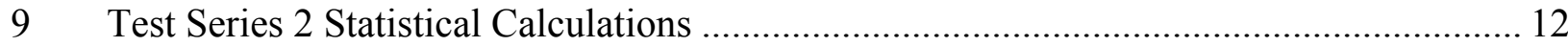

10 Test Series 2 Statistical Results for Each Mercury Measurement Method ........................... 12

11 Mercury Results for the Paired Train OH Tests - Test Series $3 \ldots \ldots \ldots \ldots \ldots \ldots \ldots \ldots \ldots \ldots \ldots \ldots \ldots \ldots \ldots . . .12$

12 Mercury Results for the Sorbent Traps and CMM - Test Series $3 \ldots \ldots \ldots \ldots \ldots \ldots \ldots \ldots \ldots \ldots \ldots \ldots \ldots \ldots . . .13$

13 Data Quality Objectives for Preparation and Analysis of Flue Gas Mercury Samples

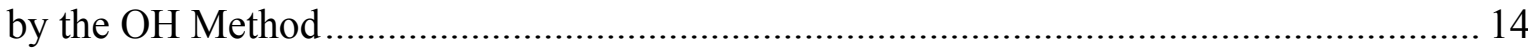

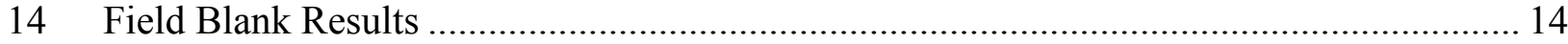

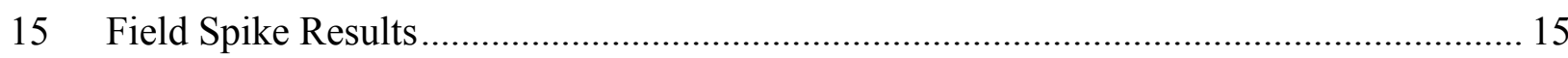

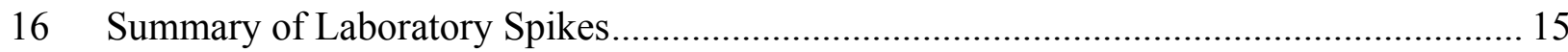

17 Calibration Standard Recoveries for the Ohio Lumex ....................................................... 16

18 Sorbent Trap Field Blanks Using the Ohio Lumex ........................................................ 16

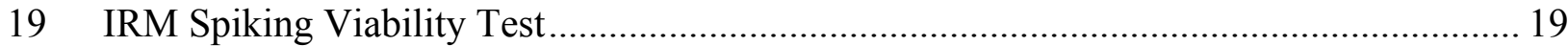

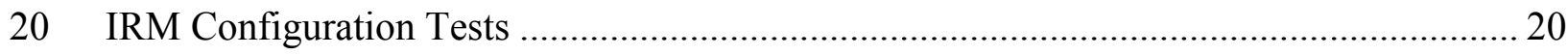

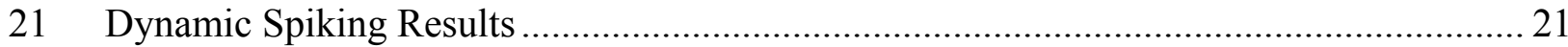




\section{EVALUATION OF ALTERNATIVES TO THE ONTARIO HYDRO METHOD AS A REFERENCE METHOD FOR CAMR}

\section{EXECUTIVE SUMMARY}

In June 2005, the U.S. Environmental Protection Agency (EPA) finalized the Clean Air Mercury Rule (CAMR). As part of the rule, all coal-fired power plants will be required to do continuous mercury measurements. This will require that an annual relative accuracy test audit (RATA) be done. The only reference methods currently allowed are the wet-chemistry methods: the Ontario Hydro (OH) mercury speciation method (ASTM D6784-02) and EPA Method 29.

Completing a RATA using the $\mathrm{OH}$ method or EPA Method 29 requires nine valid dual trains. To be valid, each of the dual trains must have a relative difference of $10 \%$ or less. This will be a challenge and very expensive. It would be much more desirable and much simpler to use an instrumental reference method (IRM) or sorbent traps as a reference method so that the results can be obtained quickly and cheaply. This report presents the results from testing at Reliant Energy, Inc.'s Portland Station (burns a low-to-medium sulfur eastern bituminous coal). The testing was designed to compare the results from sorbent traps to the $\mathrm{OH}$ method under a RATA scenario for three different conditions.

The results from twelve paired $\mathrm{OH}$ method trains were compared to data collected from 12 sets of sorbent trap samples using a quad probe. For each set of four sorbent traps, two were analyzed in the field using the Ohio Lumex mercury analyzer, and two were analyzed by Frontier Geosciences (FGS) using EPA Method 1631. All tests were done simultaneously and were 2 hours long. The results for the first two test series are shown in Table 1. When compared to the $\mathrm{OH}$ method, both sorbent trap analysis methods passed a RATA for these two tests.

Table ES-1. Statistical Mercury Results from Test Series 1
and 2
\begin{tabular}{|l|c|c|c|c|}
\hline & \multicolumn{2}{|c|}{ Test Series 1} & \multicolumn{2}{c|}{ Test Series 2} \\
\hline Analysis & $\begin{array}{c}\text { Average, } \\
\mu \mathrm{g} / \mathrm{m}^{3}\end{array}$ & $\begin{array}{c}\text { Relative } \\
\text { Accuracy, } \%\end{array}$ & $\begin{array}{c}\text { Average, } \\
\mu \mathrm{g} / \mathrm{m}^{3}\end{array}$ & $\begin{array}{c}\text { Relative } \\
\text { Accuracy, } \%\end{array}$ \\
\hline OH Method & 8.47 & - & 2.19 & - \\
\hline FGS & 8.18 & 5.07 & 2.05 & 17.00 \\
\hline Ohio Lumex & 9.47 & 18.17 & 2.14 & 9.24 \\
\hline CMM $^{*}$ & - & - & 2.43 & 17.03 \\
\hline
\end{tabular}

* Continuous Mercury Monitor.

For the third test series, a very high level of mercury control was in place, and the average mercury concentration in the flue gas was $0.19 \mu \mathrm{g} / \mathrm{m}^{3}$. At this level, it was not possible to obtain nine valid sets of $\mathrm{OH}$ method results. It should be noted that ASTM D6784-02 indicates a lower limit of $0.5 \mu \mathrm{g} / \mathrm{m}^{3}$. However, it was possible to obtain valid data sets using the sorbent traps. 

needed:

Before the sorbent trap method can be used as a reference method, the following are

- Similar tests need to be completed at facilities burning other types of coal.

- Quality Assurance/Quality Control protocols must be established for the Ohio Lumex or similar instruments that are in line with EPA Method 1631.

- EPA must recognize the sorbent trap method as a valid reference method and establish reference method protocols for sorbent traps similar to the $\mathrm{OH}$ method.

Also, an objective of this project was to do preliminary IRM testing in conjunction with the $\mathrm{OH}$ and sorbent trap sampling. The instrument that was used for the test was a PS Analytical (PSA) Sir Galahad cold-vapor atomic fluorescence (CVAF) system with a wet conversion system. One of the most important aspects of IRM testing is to be able to do dynamic spiking with both elemental and oxidized mercury. The oxidized mercury-spiking system that was to be used for the test was a system designed by the Energy \& Environmental Research Center. However, when this $\mathrm{HgCl}_{2}$ spiking system was used in an IRM testing regime, a problem occurred. It is required by the IRM protocols that both a high-and a low-range span be used. As a result, it became obvious that different mass flow controllers would be needed for each range to obtain the tolerances required by the preliminary IRM testing protocols. This was not possible for this test, but because the PSA Sir Galahad system has a gold trap that collects the mercury prior to being analyzed, it was thought that a direct manual spiking method could be employed.

Although the method showed some promise, it was clear that additional testing is needed. However, the method may not be acceptable to EPA, as it does not consider elemental mercury vapor pressure curves to be a National Institute of Standards Technology-traceable standard. 


\section{EVALUATION OF ALTERNATIVES TO THE ONTARIO HYDRO METHOD AS A REFERENCE METHOD FOR CAMR}

\subsection{INTRODUCTION}

In June 2005, the U.S. Environmental Protection Agency (EPA) finalized the Clean Air Mercury Rule (CAMR). As part of the rule, all coal-fired power plants will be required to do continuous mercury measurements. This can be done in one of two ways. The first is to install continuous mercury monitors (CMMs); the second is to use mercury sorbent traps. The protocols for doing mercury measurement are 40 Code of Federal Regulations (CFR), Parts 75 and 60. To install a CMM, the instrument must first be certified under Performance Specification (PS) 12A. Then after the CMM has been certified, the calibrations and relative accuracy test audit (RATA) protocols under 40 CFR, Part 75, Appendices A and B, must be followed. For the sorbent traps, initial certification is not required; however, 40 CFR, Part 75, Appendix K, protocols must be done. These protocols require that an annual RATA be done. To complete the RATAs as required under PS 12A and $40 \mathrm{CFR}$, Part 75, Appendices A, B, and $\mathrm{K}$, the only reference methods allowed are the wet-chemistry methods: the Ontario Hydro $(\mathrm{OH})$ mercury speciation method (ASTM International D6784-02) and EPA Method 29.

To complete a RATA using the $\mathrm{OH}$ method will require nine valid dual trains. To be valid, each of the dual trains must have a relative difference of $10 \%$ or less. In some cases, this can be a challenge and, therefore, most likely 12 or more trains will need to be completed. Because the results from the analytical laboratory most likely will not be available until after the sampling team has left the site, if nine valid sets have not been obtained, the sampling team will have to return to repeat the test. Even if the desired results are obtained, the process will be very expensive. It would be much more desirable to use either an instrumental reference method (IRM) or sorbent traps as a reference method so that the results can be obtained quickly and cheaply. This report presents the results from testing at Reliant Energy, Inc.'s Portland Station. The project was designed to compare mercury concentrations measured using sorbent traps to those obtained using the $\mathrm{OH}$ method. The tests were done using a RATA scenario and at three different conditions. In addition, as part of the project, limited IRM testing was also completed.

\subsection{PROJECT OBJECTIVES}

The overall goal of the project was to provide data to EPA and/or state regulatory agencies to prove the viability of the sorbent trap method and/or IRM as a replacement for the $\mathrm{OH}$ method as a reference method for doing RATAs. The project was piggybacked onto ALSTOM's U.S. Department of Energy (DOE)-sponsored Mer-Cure demonstration project that was being conducted at the Portland Station. As a result, the sampling was done for three different test conditions, baseline, midlevel mercury control, and high-level mercury control. Specific objectives of the testing were as follows:

- Complete a successful OH RATA under the three different conditions. 
- Compare the results of the OH RATA to simultaneously taken sorbent trap samples.

- Determine if a two-section sorbent has the potential to be used as a reference method.

- Compare the analyses of the sorbent trap samples using EPA Method 1631 to those obtained using an Ohio Lumex RA-915 portable mercury analyzer with pyrolyzing attachment.

- Compare the results from the OH RATA and sorbent traps to determine if an installed CMM would pass a RATA at the Portland Station.

- Determine what difficulties can be anticipated when attempting to complete IRM testing.

\subsection{PLANT DESCRIPTION AND OPERATION}

Reliant Energy's Portland Station has two tangentially coal-fired units (Units 1 and 2); Unit 1 is $170 \mathrm{MW}$, and Unit 2 is $250 \mathrm{MW}$. Both units burn the same low-to-medium sulfurcompliant bituminous coal and have cold-side electrostatic precipitators (ESPs). In addition, both units have overfire air for $\mathrm{NO}_{\mathrm{x}}$ control. The tests were completed on the 170-MW Unit 1. A schematic of the plant is shown in Figure 1.

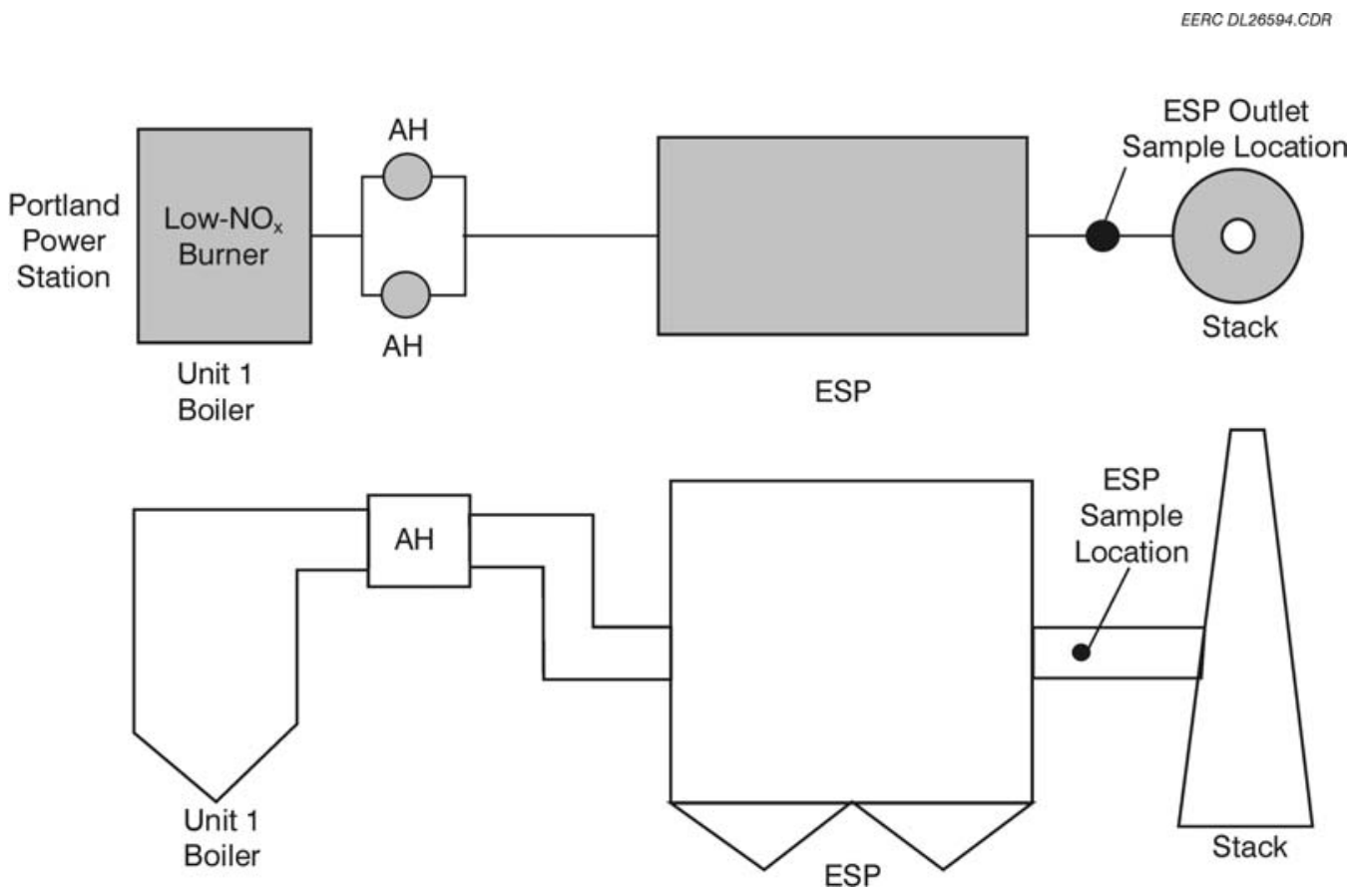

Figure 1. Schematic of Reliant Energy's Portland Power Plant, Unit 1. 


\subsection{Coal Analysis}

A typical analysis of the fuel burned at the plant is provided in Table 1 . It should be noted that there was a definite decrease in mercury concentration in the coal that occurred between the first and second series of tests. This is not unusual at a plant burning an eastern bituminous coal as most obtain coals from different mines.

\subsection{Plant Operation}

During the testing, the plant operating conditions did not vary significantly, as shown in Tables 2-4. The plant was maintained at near full load.

Table 1. Typical Coal Analysis for the Portland Power Plant

\begin{tabular}{lc}
\hline & Analysis \\
\hline Mercury, ppm (dry) & $0.05-0.15$ \\
Chlorine, ppm (dry) & 1160 \\
Proximate Analysis (as-received) & \\
$\quad$ Ash, wt $\%$ & 7.48 \\
Moisture, wt $\%$ & 7.10 \\
$\quad$ Sulfur, wt $\%$ & 1.98 \\
Heating Value, Btu/lb (as-received) & 13,150 \\
\hline
\end{tabular}

Table 2. Average Plant Data for Test Series 1

\begin{tabular}{|c|c|c|c|c|c|c|c|c|c|c|}
\hline \multirow{2}{*}{$\begin{array}{l}\text { Date: } \\
\text { Time: } \\
\text { Parameter: }\end{array}$} & \multicolumn{2}{|c|}{$\begin{array}{c}3-20-06 \\
06: 30-17: 30\end{array}$} & \multicolumn{2}{|c|}{$\begin{array}{c}3-21-06 \\
06: 00-16: 00\end{array}$} & \multicolumn{2}{|c|}{$\begin{array}{c}3-22-06 \\
06: 15-11: 45\end{array}$} & \multicolumn{2}{|c|}{$\begin{array}{c}3-23-06 \\
06: 40-15: 30\end{array}$} & \multicolumn{2}{|c|}{$\begin{array}{c}3-24-06 \\
06: 10-08: 10\end{array}$} \\
\hline & Avg. & Std. Dev. & Avg. & Std. Dev. & Avg. & Std. Dev. & Avg. & Std. Dev. & Avg. & Std. Dev. \\
\hline Load (gross), MW & 164 & 0.8 & 164 & 1.3 & 165 & 1.1 & 165 & 1.1 & 159 & 10.4 \\
\hline Load (net), MW & 151 & 0.3 & 151 & 0.9 & 151 & 0.8 & 151 & 0.9 & 135 & 18.4 \\
\hline ESP Inlet Temp., ${ }^{\circ} \mathrm{F}$ & 276 & 1.2 & 273 & 3.3 & 276 & 2.0 & 278 & 2.3 & 265 & 5.1 \\
\hline ESP Outlet Temp., ${ }^{\circ} \mathrm{F}$ & 263 & 1.9 & 261 & 5.6 & 263 & 2.8 & 268 & 3.5 & 248 & 6.5 \\
\hline $\begin{array}{l}\text { Flue Gas Flow Rate, } \\
\text { kscf } / \mathrm{hr}\end{array}$ & 22,891 & 124.0 & 22,886 & 232.3 & 22,890 & 130.2 & 22,816 & 336.8 & 22,543 & 621.2 \\
\hline $\mathrm{NO}_{\mathrm{x}}, \mathrm{ppm}$ & 162 & 4.4 & 183 & 4.8 & 177 & 4.8 & 185 & 3.6 & 147 & 8.6 \\
\hline $\mathrm{SO}_{2}, \mathrm{ppm}$ & 1104 & 22.0 & 1067 & 48.3 & 1083 & 35.4 & 1102 & 32.7 & 1041 & 68.1 \\
\hline $\mathrm{CO}_{2}, \%$ & 11.3 & 0.2 & 11.1 & 0.5 & 11.1 & 0.4 & 11.3 & 0.3 & 10.7 & 0.7 \\
\hline Boiler Outlet $\mathrm{O}_{2}, \%$ & 3.54 & 0.04 & 3.54 & 0.01 & 3.43 & 0.01 & 3.43 & 0.01 & 3.31 & 0.02 \\
\hline Opacity, \% & 2.6 & 0.1 & 2.5 & 0.5 & 2.5 & 0.3 & 2.8 & 0.3 & 3.3 & 0.2 \\
\hline
\end{tabular}


Table 3. Average Plant Data for Test Series 2

\begin{tabular}{|c|c|c|c|c|c|c|c|c|}
\hline $\begin{array}{l}\text { Date: } \\
\text { Time: }\end{array}$ & \multicolumn{2}{|c|}{$\begin{array}{c}4-18-06 \\
06: 50-16: 20\end{array}$} & \multicolumn{2}{|c|}{$\begin{array}{c}4-19-06 \\
07: 03-15: 45\end{array}$} & \multicolumn{2}{|c|}{$\begin{array}{c}4-20-06 \\
06: 30-14: 00\end{array}$} & \multicolumn{2}{|c|}{$\begin{array}{r}4-21-06 \\
07: 47-15: 00 \\
\text { Std. }\end{array}$} \\
\hline Parameter: & Avg. & Std. Dev. & Avg. & Std. Dev. & Avg. & Std. Dev. & Avg. & Dev. \\
\hline Load (gross), MW & 161 & 1.5 & 161 & 1.6 & 157 & 12.4 & 161 & 1.0 \\
\hline Load (net), MW & 145 & 6.7 & 144 & 9.6 & 138 & 18.7 & 147 & 1.0 \\
\hline ESP Inlet Temp., ${ }^{\circ} \mathrm{F}$ & 289 & 5.4 & 289 & 6.5 & 283 & 5.9 & 286 & 1.1 \\
\hline ESP Outlet Temp., ${ }^{\circ} \mathrm{F}$ & 217 & 5.5 & 282 & 7.2 & 286 & 7.7 & 279 & 1.8 \\
\hline $\begin{array}{l}\text { Flue Gas Flow Rate, } \\
\text { kscf } / \mathrm{hr}\end{array}$ & 22,563 & 129.8 & 22,070 & 231.1 & 22,316 & 128.9 & 22,724 & 123.3 \\
\hline $\mathrm{NO}_{\mathrm{x}}, \mathrm{ppm}$ & 167 & 3.5 & 154 & 5.8 & 164 & 4.4 & 168 & 3.4 \\
\hline $\mathrm{SO}_{2}, \mathrm{ppm}$ & 1115 & 14.2 & 1125 & 9.2 & 1084 & 29.1 & 998 & 42.0 \\
\hline $\mathrm{CO}_{2}, \%$ & 11.2 & 0.2 & 11.4 & 0.1 & 11.2 & 0.3 & 11.2 & 0.1 \\
\hline Boiler Outlet $\mathrm{O}_{2}, \%$ & 3.16 & 0.05 & 2.79 & 0.17 & 3.23 & 0.27 & 3.31 & 0.11 \\
\hline Opacity, \% & 3.2 & 0.4 & 3.5 & 0.6 & 3.8 & 0.3 & 3.7 & 0.2 \\
\hline
\end{tabular}

Table 4. Average Plant Data for Test Series $3 *$

\begin{tabular}{lcc|cc|cc|cc}
\hline Date: & \multicolumn{2}{c|}{$5-30-06$} & \multicolumn{2}{c|}{$6-07-06$} & \multicolumn{2}{c|}{$6-08-06$} & \multicolumn{2}{c}{$6-09-06$} \\
Time: & \multicolumn{2}{c|}{$07: 00-15: 00$} & \multicolumn{2}{c}{$09: 45-17: 15$} & \multicolumn{2}{c}{$08: 20-18: 15$} & \multicolumn{2}{c}{$08: 10-10: 42$} \\
Parameter: & Avg. & Std. Dev. & Avg. & Std. Dev. & Avg. & Std. Dev. & Avg. & Std. Dev. \\
\hline Load (gross), MW & 161 & 20.2 & 171 & 1.0 & 170 & 2.3 & 171 & 1.0 \\
Load (net), MW & 142 & 24.4 & 157 & 1.9 & 155 & 8.4 & 152 & 8.9 \\
ESP Inlet Temp., ${ }^{\circ} \mathrm{F}$ & 296 & 10.4 & 283 & 0.8 & 284 & 1.8 & 162 & 4.7 \\
ESP Outlet Temp., ${ }^{\circ} \mathrm{F}$ & 303 & 7.3 & 280 & 1.2 & 282 & 1.6 & 280 & 3.2 \\
Flue Gas Flow Rate, & 22,930 & 507.9 & 23,041 & 132.3 & 23,215 & 109.3 & 23,21 & 93.7 \\
$\quad$ kscf/hr & & & & & & & 1 & \\
$\mathrm{NO}_{\text {x }}$ ppm & 118 & 2.6 & 122 & 1.1 & 123 & 1.7 & 125 & 0.6 \\
$\mathrm{SO}_{2}$, ppm & 1154 & 38.9 & 1169 & 10.0 & 1134 & 35.0 & 1123 & 3.9 \\
$\mathrm{CO}_{2}, \%$ & 12.4 & 0.3 & 12.5 & 0.1 & 12.4 & 0.1 & 12.4 & 0.0 \\
${\mathrm{Boiler} \mathrm{Outlet} \mathrm{O}_{2}, \%}$ & 3.14 & 0.82 & 1.91 & 0.07 & 2.34 & 0.24 & 3.28 & 0.17 \\
Opacity, \% & 3.8 & 0.3 & 2.5 & 0.1 & 2.6 & 0.2 & 2.8 & 0.1 \\
\hline
\end{tabular}

* During Test Series 3 at Unit 1, in addition to low- $\mathrm{NO}_{\mathrm{x}}$ burners, the plant was also using deep staging, resulting in a $25 \%-30 \%$ decrease in $\mathrm{NO}_{\mathrm{x}}$.

\subsection{EXPERIMENTAL APPROACH}

The testing was done over three test periods (March, April, and June 2006). Each of the test series had a different level of mercury control, from baseline conditions to a very high level of control $(>90 \%)$. The discussions in Sections 3.0-6.0 pertain only to the $\mathrm{OH}$ method, sorbent traps, and CMM. The IRM testing conducted is discussed in Section 7.0.

\subsection{Sampling Procedures}

All sampling was done at the ESP outlet duct (Units 1 and 2 had a common stack). The sampling location chosen met the criteria established in EPA Method 1, and all sampling was done within 10 feet of each other. However, no traversing was done for either the $\mathrm{OH}$ method or 
sorbent traps. Prior to testing, complete flow traverse and $\mathrm{SO}_{2}$ stratification tests were done. There was very good mixing in duct, with little if any stratification. Therefore, it was decided that single-point sampling would be satisfactory. With the exception of the traversing, all tests were conducted using the RATA protocols established in CAMR (40 CFR, Part 75).

As stated in CAMR, the reference method for mercury measurement is the $\mathrm{OH}$ method; therefore, the sorbent trap and CMM results were compared to it. Twelve paired trains of $\mathrm{OH}$ method samples were completed for each test series. Simultaneously, sampling was also done using a quad probe with four 2-section sorbent traps (resulting in a total of 48 sorbent trap samples per test series). Each of the tests (both $\mathrm{OH}$ and sorbent traps) was $2 \mathrm{hr}$. Also during the testing, a CMM was operating around the clock at nearly the same location. Figure 2 is a schematic of the sorbent trap sampling system, and Figure 3 is a photograph of the two-section sorbent traps. The sampling procedures for the $\mathrm{OH}$ method followed the procedures as outlined in ASTM D6784-02.

\subsection{Analytical and Data Reduction Procedures}

At the completion of tests (after leak-checking the systems), the sorbent traps were removed, placed in plastic bags, and taken along with the $\mathrm{OH}$ sample trains to the Energy \& Environmental Research Center (EERC) trailer. The $\mathrm{OH}$ trains were digested and analyzed onsite using cold-vapor atomic adsorption (CVAA). The analysis of the $\mathrm{OH}$ samples again follows those outlined in ASTM D3684-02; however, the EERC has established additional quality assurance/quality control (QA/QC) requirements for the $\mathrm{OH}$ method as discussed in Section 7.

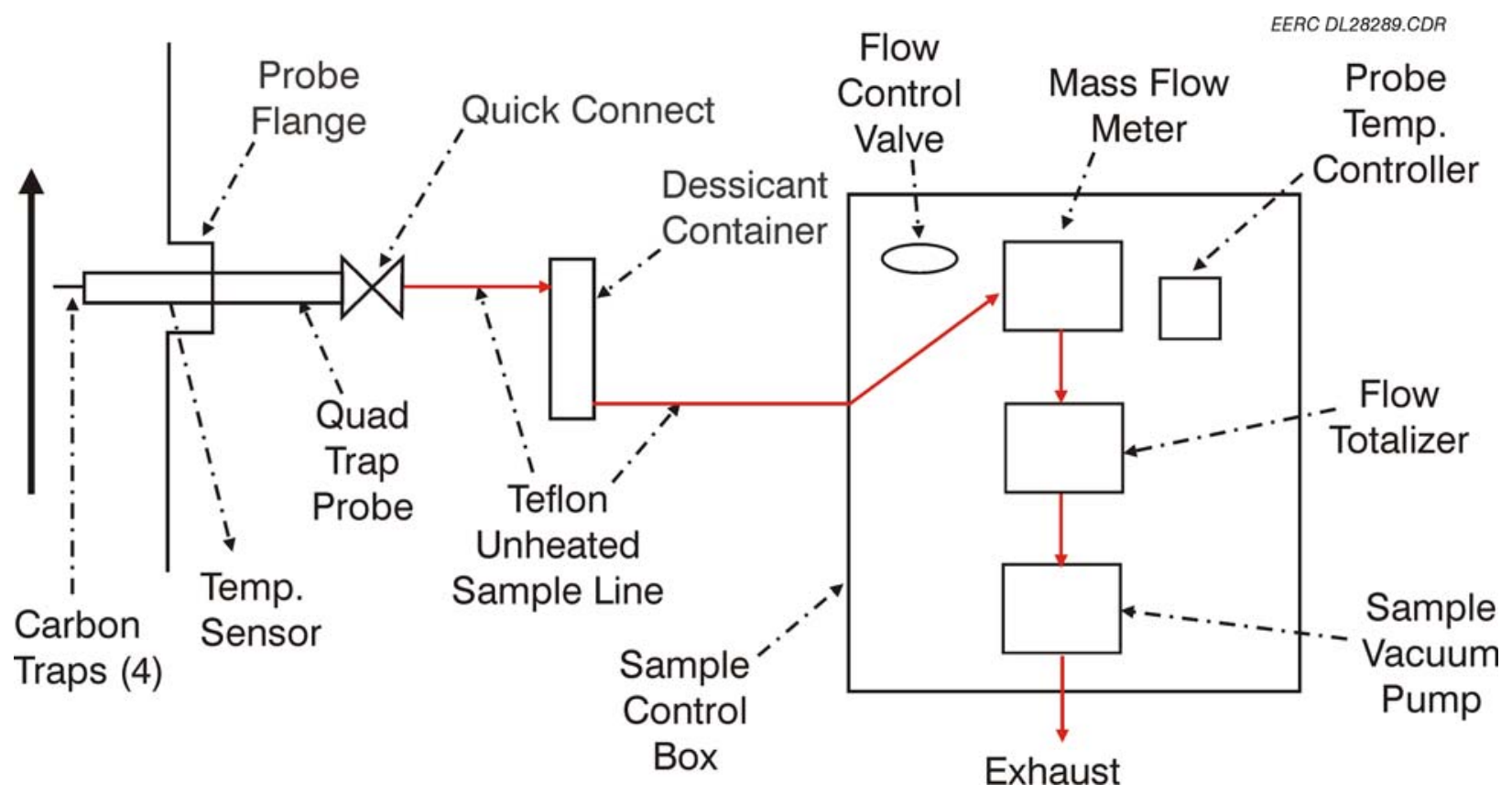

Figure 2. Schematic of sorbent trap sampling system. 


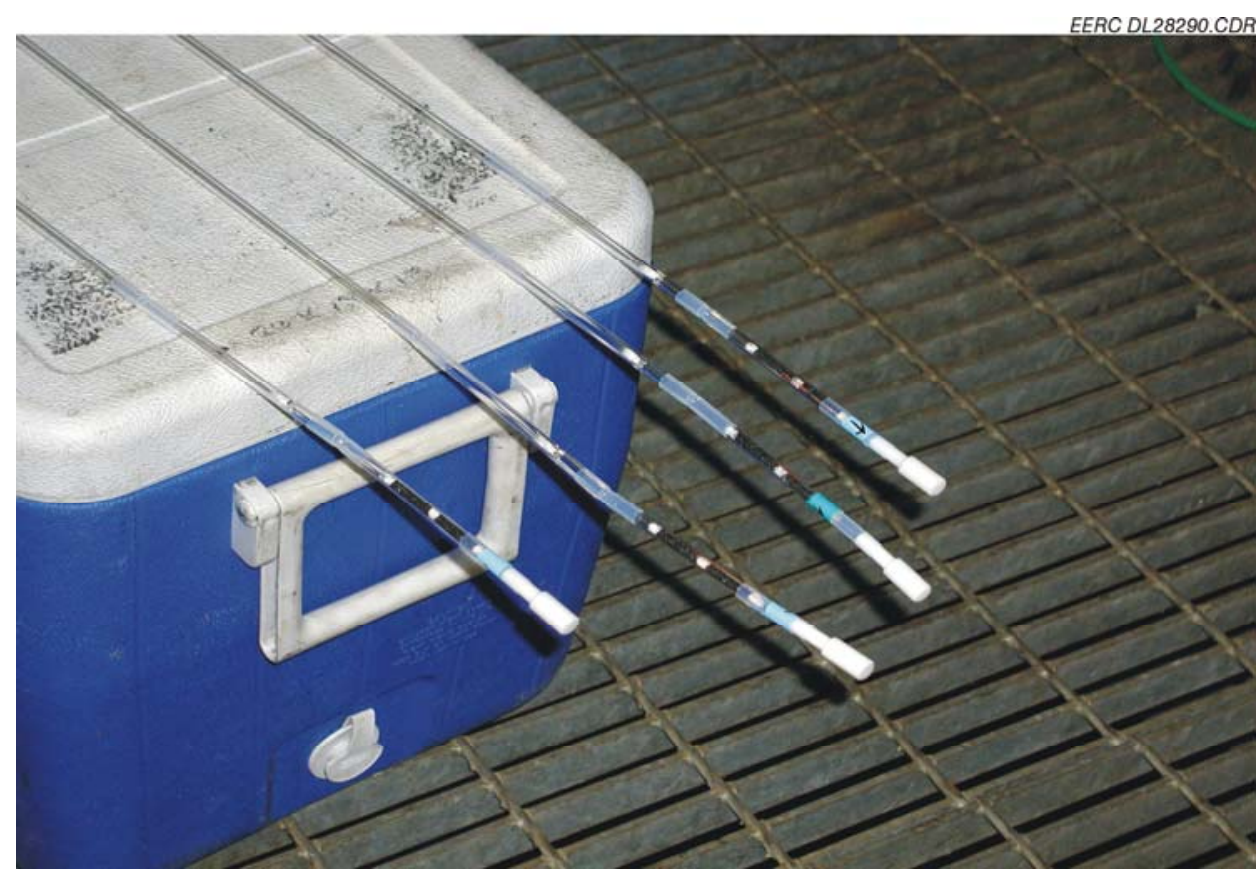

Figure 3. Photograph of sorbent traps.

Two of the four sorbent traps were packaged and shipped to Frontier Geosciences (FGS) for analysis using EPA Method 1631. The other two traps were analyzed on-site by the EERC using the Ohio Lumex instrument.

The Ohio Lumex (Lumex-915+ with RP-M 324 attachment) shown in Figure 4 is designed for on-site "direct" testing of sorbent traps. The method uses a thermal decomposition procedure that was validated by EPA. The analyzer uses CVAA, and as it is a direct method, no sample preparation is needed. A sorbent trap tube is cut, and the carbon simply transferred to a quartz ladle and inserted into the analyzer's thermocatalytic conversion chamber. The chamber is heated to $800^{\circ} \mathrm{C}$, resulting thermal decomposition of all the mercury.

The Ohio Lumex or other similar instruments have several advantages over EPA method 1631 if it can be proven they provide precise accurate data. These include the following:

- The results are obtained within 15-30 minutes, compared to 48 hours or longer if sent to a laboratory.

- Although the Ohio Lumex has an initial capital cost, it pays for itself in a relatively short period of time as laboratory analyses of these sorbent traps are expensive.

- Laboratory analyses of these samples require highly trained people in near-clean-room conditions. The Ohio Lumex is portable and relatively easy to operate and can be used in a field trailer or plant laboratory. 


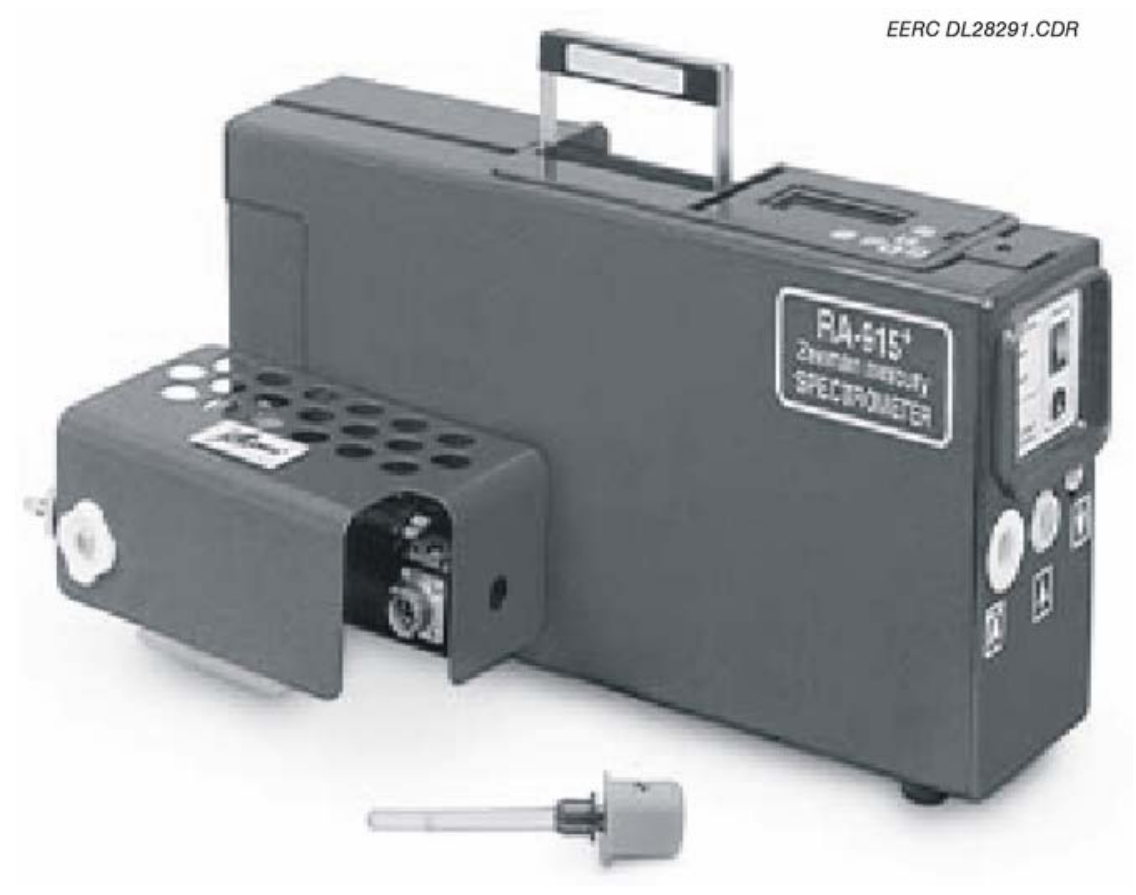

Figure 4. Ohio Lumex instrument (Lumex-915+ with RP-M 324 attachment).

The CMM that was used for all the testing at the ESP outlet location was a Tekran monitor with a PS Analytical wet pretreatment/conversion system. This CMM was operated around the clock; however, problems with the system occurred during the first test series such that the data were not valid until midway through testing.

After the analyses had been received from FGS, the results were compiled using the RATA calculations stated in $40 \mathrm{CFR}$, Part 75. The first requirement for a successful RATA is that a minimum of nine of the paired trains of the $\mathrm{OH}$ method be valid. To be valid, the relative difference between the paired trains must be $\leq 10 \%$ when the mercury concentration is $>1 \mu \mathrm{g} / \mathrm{m}^{3}$ and $\leq 20 \%$ when the mercury concentration is $\leq 1 \mu \mathrm{g} / \mathrm{m}^{3}$.

Relative difference is defined by the following equation:

$$
R D=100 \times \frac{\left|\left(C_{a}-C_{b}\right)\right|}{\left(C_{a}+C_{b}\right)}
$$

Where $C_{a}$ and $C_{b}$ are the mercury concentrations measured in the two paired sample trains.

The second requirement that must be met is that the relative accuracy of the test method compared to the $\mathrm{OH}$ method be $\leq 20 \%$, as defined by Equation 2 .

$$
\mathrm{RA}=\frac{|\overline{\mathrm{d}}|+|\mathrm{cc}|}{\mathrm{RM}} \times 100
$$


Where

$\mathrm{d}=$ the sum of the difference between the $\mathrm{OH}$ method values and the corresponding sorbent trap values.

$\mathrm{RM}=$ arithmetic mean of the $\mathrm{OH}$ method values.

$\mathrm{cc}=$ the value of the confidence coefficient as defined by Equation 3.

$$
c c=t_{0.025} \frac{\mathrm{S}_{\mathrm{d}}}{\sqrt{\mathrm{n}}}
$$

Where

$\mathrm{t}_{0.025}=$ student $\mathrm{t}$ value (use statistical tables).

$\mathrm{S}_{\mathrm{d}}=$ standard deviation.

$\mathrm{n}=$ number of data points.

\subsection{RESULTS AND DISCUSSION}

As was discussed, the testing consisted of three test periods. The mercury concentrations based on the CMM located at the ESP outlet for each of the test periods are provided in Figures 5-7. Each of the test series is described in detail in Section 4.

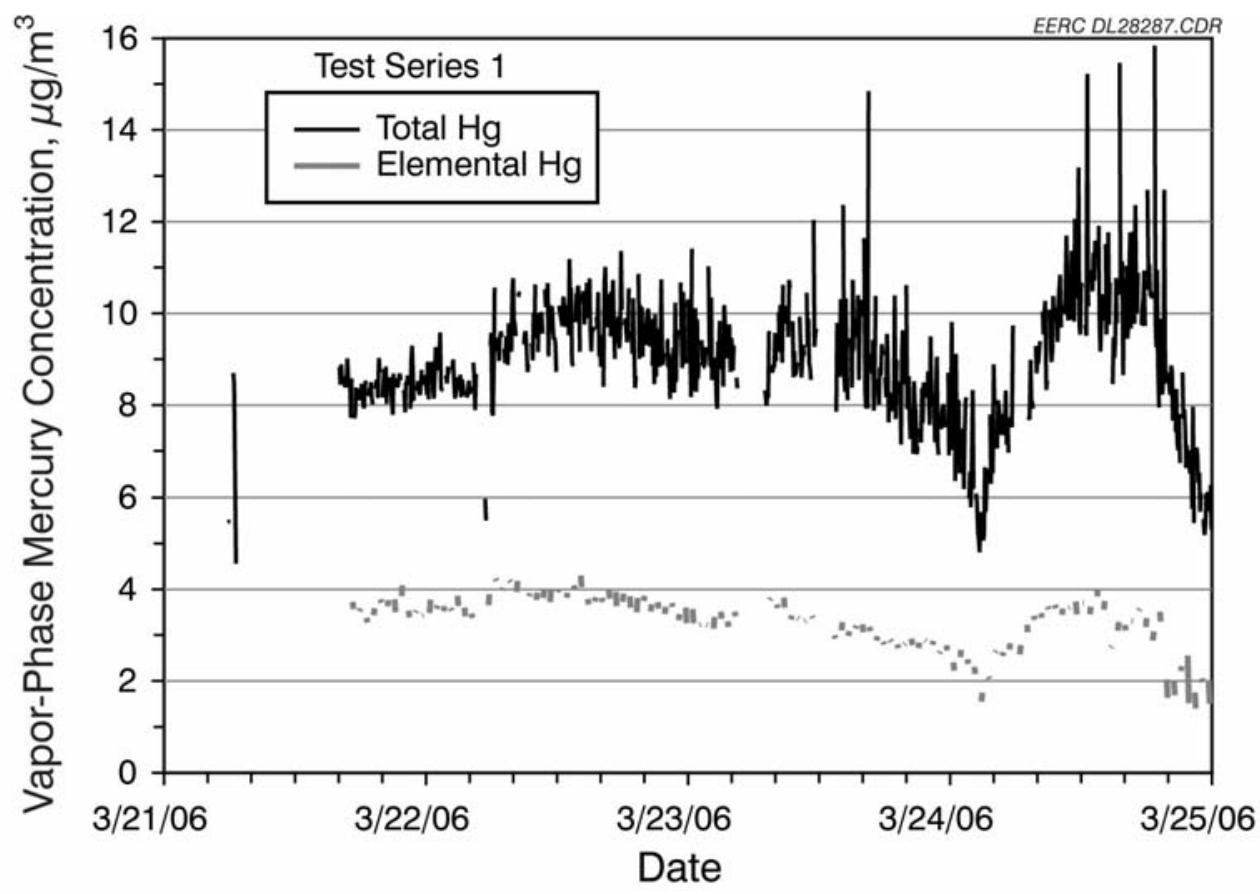

Figure 5. CMM results for baseline test (Test Series 1). 


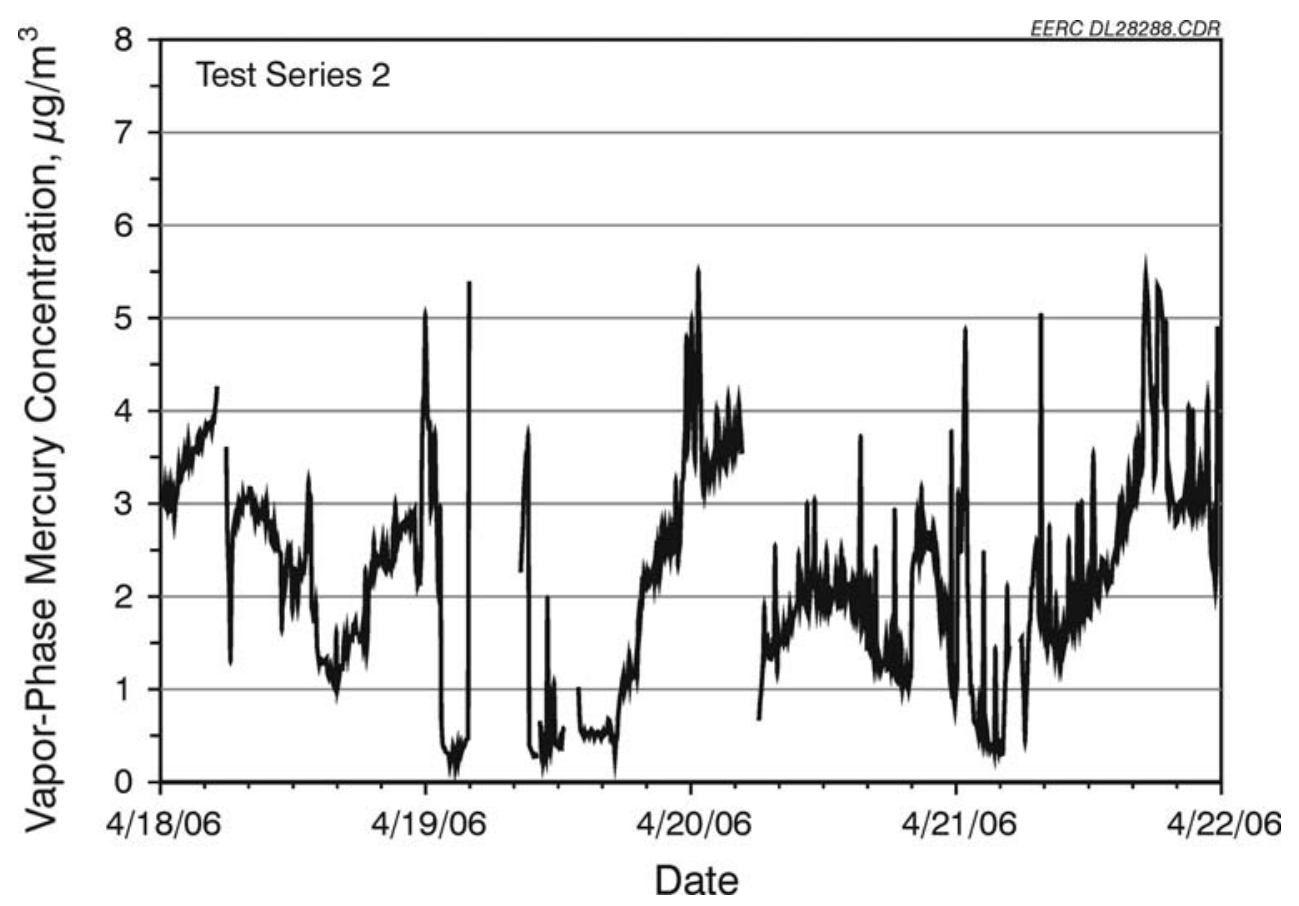

Figure 6. CMM results for Test Series 2.

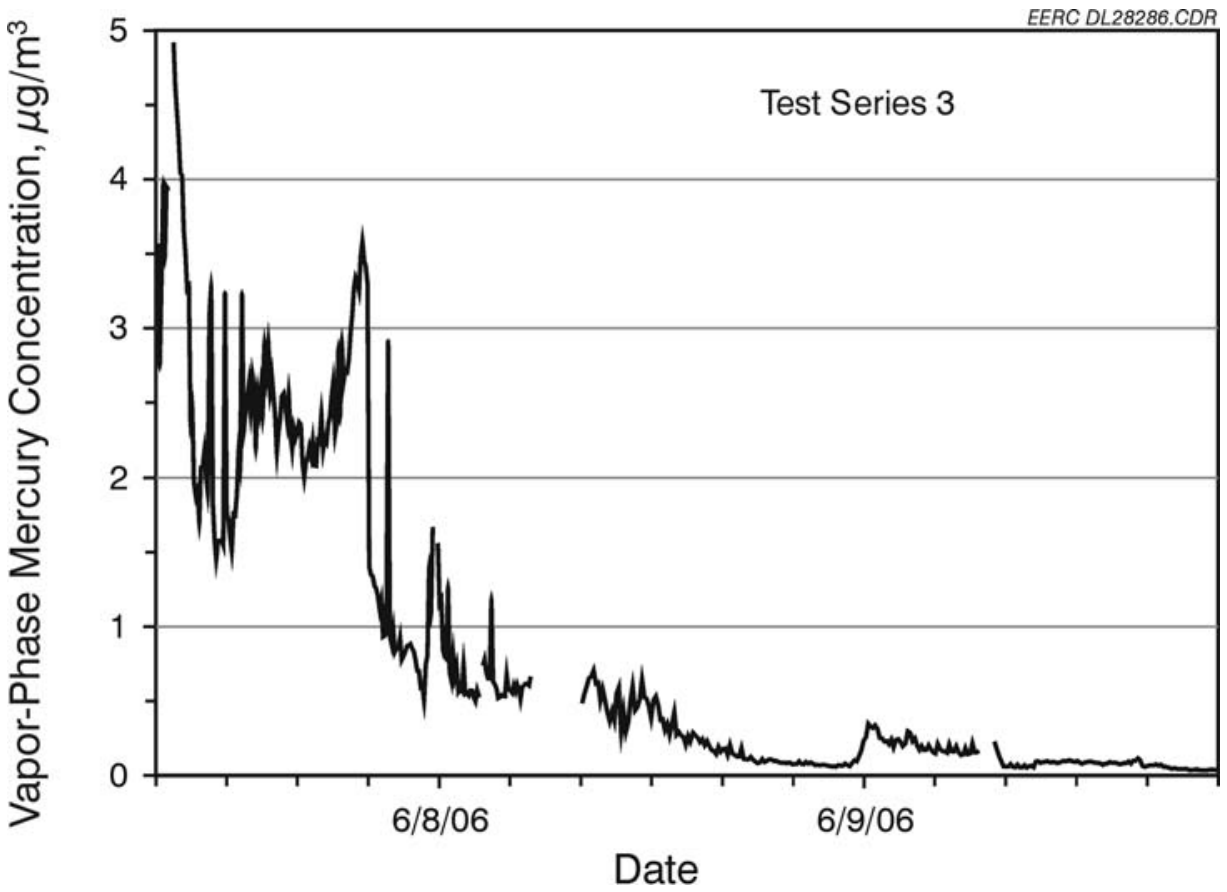

Figure 7. CMM results for Test Series 3. 


\subsection{Test Series 1 - Baseline}

The complete data set for Test Series 1 is shown in Table 5. With two exceptions (shaded in gray), all sampling meets the $10 \%$ relative difference $(\mathrm{RD})$ criteria. The two exceptions were a result of incidents that occurred that were not a result of sampling. For the $\mathrm{OH}$ testing, a crack occurred in a U-tube during sampling (discovered during the post-leak check), and for the Ohio Lumex sample, a power glitch occurred during the analysis so that the sample did not go to completion. The average values shown in Table 5 do not include these two data sets.

After eliminating the two data sets discussed above and one other as allowed by RATA requirements (nine valid data sets required), the relative accuracy and bias adjustment factor was calculated for both analysis methods for the sorbent traps, and both passed as shown in Tables 6 and 7. Although passing, there was some concern that the Ohio Lumex gave higher results than those obtained by FGS. The exact reason for this is unknown and may simply be a coincidence, as the data obtained from Test Series 2 and 3 (Section 4.2 and 4.3) were considerably more random.

\subsection{Test Series 2 - Midlevel Mercury Control}

The complete data set for Test Series 2 is shown in Table 8. There was one paired set for each of the three methods that did not meet the requisite RD. Two of the data sets analyzed by FGS had a RD $>10 \%$, but the mercury value was $<1 \mu \mathrm{g} / \mathrm{m}^{3}$, so the requirement was $20 \%$.

Table 5. Mercury Measurement Comparisons at Reliant's Portland Station - Test Series 1*

\begin{tabular}{|c|c|c|c|c|c|c|c|c|c|c|c|c|c|}
\hline \multirow[b]{2}{*}{ Sample } & \multicolumn{4}{|c|}{ Ohio Lumex - Sorbent Traps, $\mu \mathrm{g} / \mathrm{m}^{3}$} & \multicolumn{4}{|c|}{$\begin{array}{c}\text { FGS - Sorbent Traps, } \\
\mu \mathrm{g} / \mathrm{m}^{3}\end{array}$} & \multicolumn{4}{|c|}{$\begin{array}{c}\text { EERC }-\mathrm{OH} \\
\mu \mathrm{g} / \mathrm{m}^{3} \\
\end{array}$} & \multirow{2}{*}{$\begin{array}{l}\text { CMM, } \\
\mu \mathrm{g} / \mathrm{m}^{3} \\
\\
\text { Avg. }\end{array}$} \\
\hline & 1 & 2 & Avg. & $\mathrm{RD}, \%$ & 1 & 2 & Avg. & $\begin{array}{c}\mathrm{RD}, \\
\%\end{array}$ & 1 & 2 & Avg. & $\mathrm{RD}, \%$ & \\
\hline 1 & 8.13 & 8.09 & 8.11 & 0.26 & 7.65 & 7.66 & 7.66 & 0.06 & 7.62 & 1.60 & 4.61 & 65.23 & - \\
\hline 2 & 8.37 & 8.51 & 8.44 & 0.87 & 7.63 & 7.90 & 7.77 & 1.78 & 8.13 & 8.48 & 8.31 & 2.10 & - \\
\hline 3 & 7.77 & 9.10 & 8.43 & 7.86 & 7.82 & 7.82 & 7.82 & 0.01 & 8.19 & 8.25 & 8.22 & 0.35 & - \\
\hline 4 & 10.09 & 10.15 & 10.12 & 0.33 & 8.76 & 8.55 & 8.65 & 1.22 & 9.31 & 7.93 & 8.62 & 8.01 & - \\
\hline 5 & 9.47 & 10.10 & 9.79 & 3.21 & 8.26 & 7.99 & 8.13 & 1.67 & 9.23 & 7.91 & 8.57 & 7.73 & - \\
\hline 6 & 10.13 & 10.23 & 10.18 & 0.48 & 8.50 & 8.46 & 8.48 & 0.23 & 9.52 & 9.74 & 9.63 & 1.16 & - \\
\hline 7 & 10.26 & 10.25 & 10.26 & 0.08 & 8.50 & 8.99 & 8.74 & 2.83 & 8.16 & 7.91 & 8.04 & 1.54 & 9.6 \\
\hline 8 & 10.49 & 10.12 & 10.30 & 1.77 & 8.40 & 8.97 & 8.69 & 3.29 & 8.36 & 8.03 & 8.20 & 2.01 & 9.9 \\
\hline 9 & 10.82 & 9.84 & 10.33 & 4.74 & 8.39 & 8.43 & 8.41 & 0.22 & 8.22 & 8.83 & 8.52 & 3.57 & 8.6 \\
\hline 10 & 8.96 & 10.27 & 9.62 & 6.79 & 8.58 & 8.02 & 8.30 & 3.37 & 8.95 & 8.31 & 8.63 & 3.70 & 8.9 \\
\hline 11 & 8.23 & 9.98 & 9.11 & 9.64 & 8.52 & 8.92 & 8.72 & 2.27 & 9.08 & 9.06 & 9.07 & 0.11 & 9.3 \\
\hline 12 & 8.33 & 4.18 & 6.25 & 33.15 & 6.64 & 6.85 & 6.75 & 1.56 & 7.28 & 7.18 & 7.23 & 0.71 & 7.1 \\
\hline Average & & & 9.52 & & & & 8.31 & & & & 8.46 & & 8.90 \\
\hline
\end{tabular}


Table 6. Test Series 1 Statistical Calculations

\begin{tabular}{lcccccc}
\hline & $\begin{array}{c}\text { RM }(\mathrm{OH}) \\
\text { Average, } \\
\mu \mathrm{g} / \mathrm{m}^{3}\end{array}$ & $\begin{array}{c}\text { Std Dev., } \\
\mu \mathrm{g} / \mathrm{m}^{3}\end{array}$ & $\mathrm{t}(0.025)$ & $\mathrm{cc}$ & $\overline{\mathrm{d}}$ & $\begin{array}{c}\text { Relative } \\
\text { Accuracy, } \\
\%\end{array}$ \\
Sample & 8.46 & 0.763 & 2.306 & 0.586 & -0.95 & 18.17 \\
Sorbent Trap - Ohio Lumex & 8.46 & 0.431 & 2.306 & 0.331 & 0.10 & 5.07 \\
Sorbent Trap - FGS & & &
\end{tabular}

Table 7. Test Series 1 Statistical Results for Each Mercury Measurement Method

\begin{tabular}{lcccc}
\hline & Relative & & \multicolumn{2}{c}{ Bias Adjustment } \\
Method & Accuracy, $\%$ & Results* & Bias Test & Factor \\
\hline Sorbent Trap - Ohio Lumex & 18.17 & Passed & $-0.95<0.586$ & 1.0 \\
Sorbent Trap - FGS & 5.07 & Passed & $0.1<0.331$ & 1.0 \\
CMM & - & - & - & - \\
\hline * To pass, the relative accuracy must be $\leq 20 \%$ & & &
\end{tabular}

* To pass, the relative accuracy must be $\leq 20 \%$.

Table 8. Mercury Measurement Comparisons at Reliant's Portland Station - Test Series 2*

\begin{tabular}{|c|c|c|c|c|c|c|c|c|c|c|c|c|c|}
\hline \multirow[b]{2}{*}{ Sample } & \multicolumn{4}{|c|}{$\begin{array}{c}\text { Ohio Lumex - Sorbent Traps, } \\
\mu \mathrm{g} / \mathrm{m}^{3}\end{array}$} & \multicolumn{4}{|c|}{$\begin{array}{c}\text { FGS - Sorbent Traps, } \\
\mu \mathrm{g} / \mathrm{m}^{3}\end{array}$} & \multicolumn{4}{|c|}{$\begin{array}{c}\text { EERC }-\mathrm{OH}, \\
\mu \mathrm{g} / \mathrm{m}^{3}\end{array}$} & \multirow{2}{*}{$\begin{array}{c}\text { CMM, } \\
\mu \mathrm{g} / \mathrm{m}^{3}\end{array}$} \\
\hline & 1 & 2 & Avg. & $\begin{array}{c}\mathrm{RD}, \\
\%\end{array}$ & 1 & 2 & Avg. & $\begin{array}{c}\mathrm{RD}, \\
\%\end{array}$ & 1 & 2 & Avg. & $\mathrm{RD}, \%$ & \\
\hline 1 & 2.01 & 2.45 & 2.23 & 9.80 & 2.82 & 2.84 & 2.83 & 0.48 & 2.84 & 2.93 & 2.89 & 1.57 & 3.82 \\
\hline 2 & 2.04 & 2.12 & 2.08 & 2.15 & 2.22 & 2.06 & 2.14 & 3.74 & 2.19 & 2.24 & 2.21 & 1.24 & 2.99 \\
\hline 3 & 1.06 & 0.99 & 1.03 & 3.43 & 0.61 & 0.76 & 0.69 & 10.82 & 1.13 & 1.13 & 1.13 & 0.19 & 1.57 \\
\hline 4 & 3.11 & 3.42 & 3.26 & 4.75 & 3.36 & 3.25 & 3.30 & 1.73 & 2.94 & 3.37 & 3.15 & 6.74 & 3.64 \\
\hline 5 & 0.47 & 0.49 & 0.48 & 2.26 & 0.49 & 0.56 & 0.52 & 6.18 & 0.47 & 0.57 & 0.52 & 9.71 & 0.69 \\
\hline 6 & 0.57 & 0.60 & 0.58 & 2.01 & 0.47 & 0.61 & 0.54 & 12.44 & 0.67 & 0.63 & 0.65 & 3.06 & 0.72 \\
\hline 7 & 2.10 & 2.23 & 2.17 & 3.09 & 1.97 & 2.04 & 2.00 & 1.66 & 2.04 & 2.29 & 2.17 & 5.80 & 1.96 \\
\hline 8 & 2.98 & 3.02 & 3.00 & 0.59 & 2.85 & 2.60 & 2.72 & 4.70 & 2.50 & 3.15 & 2.83 & 11.37 & 2.69 \\
\hline 9 & 3.18 & 2.79 & 2.99 & 6.39 & 2.37 & 2.69 & 2.53 & 6.16 & 3.05 & 3.19 & 3.12 & 2.20 & 2.64 \\
\hline 10 & 1.64 & 2.06 & 1.85 & 11.49 & 1.93 & 1.89 & 1.91 & 0.90 & 1.91 & 2.32 & 2.12 & 9.77 & 2.18 \\
\hline 11 & 2.60 & 2.66 & 2.63 & 1.10 & 2.01 & 2.92 & 2.46 & 18.41 & 2.85 & 2.90 & 2.88 & 0.95 & 3.07 \\
\hline 12 & 3.32 & 3.41 & 3.37 & 1.24 & 3.02 & 2.77 & 2.90 & 4.27 & 3.71 & 3.82 & 3.77 & 1.36 & 3.13 \\
\hline Average & & & 2.14 & & & & 2.05 & & & & 2.19 & & 2.43 \\
\hline
\end{tabular}

* Shaded areas are those that did not meet the paired train criteria.

After eliminating the data sets discussed above and one other as allowed by RATA requirements (nine valid data sets required), the relative accuracy and bias adjustment factor was calculated for both analysis methods of the sorbent traps and for the CMM. All three methods passed the RATA, as shown in Tables 9 and 10. For Test Series 2, the relative accuracy using the Ohio Lumex to analyze the sorbent traps was better than that obtained by FGS.

\subsection{Test Series 3 - High-Level Mercury Control}

As can be seen in Table 11, the mercury measurements were very low for all the tests, with almost all below $0.5 \mu \mathrm{g} / \mathrm{m}^{3}$. According to the method as presented in ASTM D6784-02, 
Table 9. Test Series 2 Statistical Calculations

\begin{tabular}{lcccccc}
\hline & $\begin{array}{c}\text { RM }(\mathrm{OH}) \\
\text { Average, } \\
\mu \mathrm{g} / \mathrm{m}^{3}\end{array}$ & $\begin{array}{c}\text { Std Dev., } \\
\mu \mathrm{g} / \mathrm{m}^{3}\end{array}$ & $\mathrm{t}(0.025)$ & $\mathrm{cc}$ & $\overline{\mathrm{d}}$ & $\begin{array}{c}\text { Relative } \\
\text { Sccuracy, }\end{array}$ \\
\hline Somple & 2.18 & 0.174 & 2.306 & 0.134 & 0.07 & 9.24 \\
Sorbent Trap - Ohio Lumex Trap - FGS & 2.00 & 0.226 & 2.306 & 0.174 & 0.17 & 17.00 \\
CMM & 2.17 & 0.372 & 2.306 & 0.286 & -0.08 & 17.03 \\
\hline
\end{tabular}

Table 10. Test Series 2 Statistical Results for Each Mercury Measurement Method

\begin{tabular}{|c|c|c|c|c|}
\hline Method & $\begin{array}{c}\text { Relative } \\
\text { Accuracy, } \\
\%\end{array}$ & Results* & Bias Test & $\begin{array}{c}\text { Bias } \\
\text { Adjustment } \\
\text { Factor }\end{array}$ \\
\hline Sorbent Trap - Ohio Lumex & 9.24 & Passed & $0.07<0.134$ & 1.0 \\
\hline Sorbent Trap-FGS & 17.00 & Passed & $0.17<0.174$ & 1.0 \\
\hline CMM & 17.03 & Passed & $-0.08<0.286$ & 1.0 \\
\hline
\end{tabular}

* To pass, the relative accuracy must be $\leq 20 \%$.

Table 11. Mercury Results for the Paired Train OH Tests - Test Series $3^{\mathrm{a}}$

\begin{tabular}{|c|c|c|c|c|c|c|c|c|}
\hline \multirow[b]{2}{*}{ Sample } & \multicolumn{4}{|c|}{$\begin{array}{c}\text { OH Samples, } \\
\mu \mathrm{g} / \mathrm{m}^{3}\end{array}$} & \multicolumn{4}{|c|}{$\mathrm{OH} \mathrm{Samples,}_{\mu \mathrm{c} / \mathrm{m}^{3}}$} \\
\hline & 1 & 2 & Avg. & $\mathrm{RD}, \%$ & 1 & 2 & Avg. & $\mathrm{RD}, \%$ \\
\hline 1 & 0.30 & 0.65 & 0.48 & 36.63 & 0.30 & 0.65 & 0.48 & 36.63 \\
\hline 2 & 0.21 & 0.33 & 0.27 & 22.97 & 0.22 & 0.33 & 0.28 & 19.14 \\
\hline 3 & 0.20 & 0.24 & 0.22 & 8.60 & 0.23 & 0.30 & 0.27 & 13.74 \\
\hline 4 & 0.52 & 0.41 & 0.46 & 11.39 & 0.52 & 0.41 & 0.47 & 11.93 \\
\hline 5 & 0.30 & 0.36 & 0.33 & 8.97 & 0.30 & 0.36 & 0.33 & 8.97 \\
\hline 6 & 0.10 & 0.19 & 0.14 & 32.41 & 0.11 & 0.22 & 0.17 & 31.45 \\
\hline 7 & 0.09 & 0.14 & 0.11 & 22.17 & 0.10 & 0.14 & 0.12 & 16.51 \\
\hline 8 & 0.15 & 0.26 & 0.20 & 27.99 & 0.15 & 0.26 & 0.21 & 27.24 \\
\hline 9 & 0.13 & 0.24 & 0.19 & 28.43 & 0.14 & 0.24 & 0.19 & 24.71 \\
\hline 10 & 0.11 & 0.32 & 0.21 & 48.79 & 0.13 & 0.32 & 0.22 & 43.16 \\
\hline 11 & 0.26 & 0.32 & 0.29 & 10.78 & 0.26 & 0.32 & 0.29 & 10.78 \\
\hline 12 & 0.34 & 0.48 & 0.41 & 16.61 & 0.37 & 0.48 & 0.42 & 13.08 \\
\hline Average & & & 0.28 & & & & 0.29 & \\
\hline
\end{tabular}

$0.5 \mu \mathrm{g} / \mathrm{m}^{3}$ is the lowest level at which the method is valid. Regardless of how nondetected samples are handled, it is clear that we were unable to obtain nine paired train samples that met the $20 \% \mathrm{RD}$ criteria as required. However, this was not true for the sorbent trap samples, as nine valid sets were obtained whether the traps were analyzed by FGS or using the Ohio Lumex, as shown in Table 12. 


\begin{tabular}{|c|c|c|c|c|c|c|c|c|c|}
\hline \multirow[b]{2}{*}{ Sample } & \multicolumn{4}{|c|}{$\begin{array}{c}\text { Ohio Lumex - Sorbent Traps, } \\
\mu \mathrm{g} / \mathrm{m}^{3}\end{array}$} & \multicolumn{4}{|c|}{$\begin{array}{c}\text { FGS - Sorbent Traps, } \\
\mu \mathrm{g} / \mathrm{m}^{3}\end{array}$} & \multirow{2}{*}{$\begin{array}{l}\mathrm{CMM}, \\
\mu \mathrm{g} / \mathrm{m}^{3}, \\
\text { Avg. }\end{array}$} \\
\hline & 1 & 2 & Avg. & $\mathrm{RD}, \%$ & 1 & 2 & Avg. & $\mathrm{RD}, \%$ & \\
\hline 1 & 0.22 & 0.23 & 0.22 & 3.72 & 0.18 & 0.21 & 0.20 & 6.67 & 0.88 \\
\hline 2 & 0.17 & 0.14 & 0.15 & 7.79 & 0.15 & 0.14 & 0.15 & 0.43 & 0.37 \\
\hline 3 & 0.06 & 0.17 & 0.12 & 47.33 & 0.12 & 0.11 & 0.11 & 4.78 & 0.22 \\
\hline 4 & 0.54 & 0.59 & 0.57 & 4.08 & 0.43 & 0.44 & 0.44 & 0.77 & 0.47 \\
\hline 5 & 0.35 & 0.30 & 0.32 & 7.96 & 0.25 & 0.26 & 0.26 & 1.88 & 0.30 \\
\hline 6 & 0.11 & 0.11 & 0.11 & 4.18 & 0.09 & 0.10 & 0.09 & 4.36 & 0.16 \\
\hline 7 & 0.17 & 0.11 & 0.14 & 19.83 & 0.09 & 0.09 & 0.09 & 1.72 & 0.07 \\
\hline 8 & 0.13 & 0.16 & 0.15 & 7.74 & 0.11 & 0.12 & 0.12 & 1.22 & 0.09 \\
\hline 9 & 0.13 & 0.12 & 0.12 & 3.23 & 0.11 & 0.11 & 0.11 & 1.11 & 0.09 \\
\hline 10 & 0.02 & 0.09 & 0.06 & 58.73 & 0.03 & 0.06 & 0.03 & 30.52 & 0.05 \\
\hline 11 & 0.19 & 0.29 & 0.24 & 21.33 & 0.22 & 0.22 & 0.22 & 1.14 & 0.15 \\
\hline 12 & 0.20 & 0.27 & 0.23 & 13.80 & 0.31 & 0.28 & 0.30 & 4.07 & 0.21 \\
\hline Average & & & 0.20 & & & & 0.18 & & 0.26 \\
\hline
\end{tabular}

* Shaded areas are those sets that do not meet paired trap requirements.

If the sorbent traps were used as a reference method to complete a RATA for the OH monitor, the relative accuracy would be $23.82 \%$. Although slightly greater than $20 \%$, the monitor would pass as the absolute mercury concentration for the valid sorbent trap tests is $<1 \mu \mathrm{g} / \mathrm{m}^{3}$.

\subsection{QUALITY ASSURANCE/QUALITY CONTROL}

\subsection{OH Method}

The data quality objectives for the $\mathrm{OH}$ testing are shown in Table 13. The QC results for the field blanks and spikes are shown in Tables 14-16. The reagent and field blanks were very low for all the tests. In fact all the field blanks were $<0.1 \mu \mathrm{g} / \mathrm{L}$, and many were below the detection limit of $0.03 \mu \mathrm{g} / \mathrm{L}$. Although several of the individual solution spike recoveries (three $\mathrm{KCl}$ and three $\mathrm{H}_{2} \mathrm{O}_{2}$ ) were a bit higher than would be expected, most were well below the $20 \%$ criteria. The average in all cases easily met the objectives listed in Table 13. All tests were completed as planned.

\subsection{Sorbent Traps}

All the sorbent traps used for the testing at the Portland Station were purchased from FGS. FGS is recognized as the expert for manufacturing and analyzing these traps using EPA Method 1631. Although data quality objectives have not yet been established for analyzing sorbent traps using the Ohio Lumex, the EERC did have a QA plan in place. All calibrations of the instrument for the Portland project were done using known mercury solutions. In addition, field blanks were also analyzed. A sorbent trap field blank is similar to those for the $\mathrm{OH}$ method. For each day of sampling, an unused trap is taken to the sample location; after the sampling is completed, the field blank trap is analyzed with the other traps. As stated above, all EPA Method 1631 analyses of the sorbent traps were done by FGS. FGS has rigorous QA/QC procedures in place for 
Table 13. Data Quality Objectives for Preparation and Analysis of Flue Gas Mercury Samples by the OH Method

\begin{tabular}{|c|c|c|c|}
\hline Measure & Sample Type & Objective & Approach \\
\hline Accuracy & Field spike & $80 \%-120 \%$ of known value & $\begin{array}{l}\text { Collect and analyze one field spike for } \\
\text { each unit per day of testing (analysis } \\
\text { must be done on each solution) }\end{array}$ \\
\hline Accuracy & $\begin{array}{l}\text { Laboratory } \\
\text { method and } \\
\text { instrument spikes }\end{array}$ & $85 \%-115 \%$ of known value & $\begin{array}{l}\text { Frequency of one per batch per solution } \\
\text { type or } 10 \% \text {, whichever is greater }\end{array}$ \\
\hline Accuracy & $\begin{array}{l}\text { Reference } \\
\text { material }\end{array}$ & $\begin{array}{c}85 \%-115 \% \text { of reference } \\
\text { value }\end{array}$ & Frequency of one per test program \\
\hline Precision & $\begin{array}{l}\text { Replicate } \\
\text { analyses }\end{array}$ & $\begin{array}{c} \pm 10 \% \text { of the previous } \\
\text { analysis }\end{array}$ & $\begin{array}{l}\text { Frequency of one per batch per solution } \\
\text { type or } 10 \% \text {, whichever is greater }\end{array}$ \\
\hline Contamination & Reagent blank & $\begin{array}{l}<0.1 \mu \mathrm{g} / \mathrm{L} \text { or } 10 \times \text { the } \\
\text { instrument detection limit, } \\
\text { whichever is greater }\end{array}$ & $\begin{array}{c}\text { Analyze one blank per batch of each } \\
\text { reagent }\end{array}$ \\
\hline Contamination & Field blank & $\begin{array}{c}<30 \% \text { of sampled mercury } \\
\text { concentration or }<0.2 \mu \mathrm{g}^{*} \text { in } \\
\text { the complete train, } \\
\text { whichever is lower }\end{array}$ & $\begin{array}{l}\text { Collect and analyze one field blank for } \\
\text { each unit per day of testing (analysis } \\
\text { must be done on each solution) }\end{array}$ \\
\hline
\end{tabular}

Table 14. Field Blank Results

\begin{tabular}{lccc}
\hline Date & $\mathrm{KCl} \mathrm{Soln.,} \mu \mathrm{g} / \mathrm{L}$ & $\mathrm{H}_{2} \mathrm{O}_{2}$ Soln., $\mu \mathrm{g} / \mathrm{L}$ & $\mathrm{KMnO}_{4}$ Soln., $\mu \mathrm{g} / \mathrm{L}$ \\
\hline $03 / 20 / 06$ & 0.04 & $<0.03$ & $<0.03$ \\
$03 / 21 / 06$ & 0.07 & $<0.03$ & 0.05 \\
$03 / 22 / 06$ & 0.03 & 0.03 & $<0.03$ \\
$03 / 22 / 06$ & 0.06 & & \\
$03 / 23 / 06$ & 0.05 & $<0.03$ & 0.05 \\
$03 / 24 / 06$ & 0.03 & $<0.03$ & 0.04 \\
$03 / 27 / 06$ & 0.05 & $<0.03$ & 0.01 \\
$03 / 28 / 06$ & 0.04 & 0.03 & 0.03 \\
$04 / 18 / 06$ & 0.03 & $<0.03$ & $<0.03$ \\
$04 / 19 / 06$ & $<0.03$ & $<0.03$ & $<0.03$ \\
$04 / 20 / 06$ & 0.07 & 0.04 & 0.03 \\
$04 / 21 / 06$ & 0.06 & $<0.03$ & 0.03 \\
$04 / 24 / 06$ & 0.08 & 0.05 & 0.04 \\
$05 / 31 / 06$ & 0.070 & 0.050 & $<0.03$ \\
$05 / 31 / 06$ & $<0.03$ & & \\
$05 / 31 / 06$ & $<0.03$ & & $<0.03$ \\
$06 / 06 / 06$ & $<0.03$ & $<0.03$ & $<0.03$ \\
$06 / 07 / 06$ & $<0.03$ & $<0.03$ & \\
$06 / 07 / 06$ & $<0.03$ & & $<0.03$ \\
$06 / 08 / 06$ & $<0.03$ & $<0.03$ & $<0.03$ \\
$06 / 09 / 06$ & $<0.03$ & $<0.03$ & 0.03 \\
$06 / 10 / 06$ & $<0.03$ & $<0.03$ & \\
\hline
\end{tabular}


Table 15. Field Spike Results*

\begin{tabular}{l|ccc|ccc|ccc|}
\hline & \multicolumn{3}{|c|}{ KCl Soln. } & \multicolumn{3}{c|}{$\mathrm{H}_{2} \mathrm{O}_{2}$ Soln. } & \multicolumn{3}{c|}{$\mathrm{KMnO}_{4}$ Soln. } \\
\cline { 2 - 9 } Date & $\begin{array}{c}\text { Spike, } \\
\text { ppm }\end{array}$ & $\begin{array}{c}\text { Reading, } \\
\text { ppm }\end{array}$ & $\begin{array}{c}\text { Recovery, } \\
\%\end{array}$ & $\begin{array}{c}\text { Spike, } \\
\text { ppm }\end{array}$ & $\begin{array}{c}\text { Reading, } \\
\text { ppm }\end{array}$ & $\begin{array}{c}\text { Recovery, } \\
\%\end{array}$ & $\begin{array}{c}\text { Spike, } \\
\text { ppm }\end{array}$ & $\begin{array}{c}\text { Reading, } \\
\text { ppm }\end{array}$ & $\begin{array}{c}\text { Recovery, } \\
\%\end{array}$ \\
\hline $03 / 20 / 06$ & 5 & 5.59 & 111.72 & 2 & 2.27 & 113.64 & 5 & 5.18 & 103.50 \\
$03 / 21 / 06$ & 10 & 11.28 & 112.84 & 2 & 2.12 & 106.17 & 5 & 5.75 & 115.00 \\
$03 / 22 / 06$ & 10 & 10.16 & 101.57 & 2 & 2.16 & 107.96 & 5 & 4.90 & 97.90 \\
$03 / 23 / 06$ & 10 & 10.70 & 106.96 & 3 & 3.27 & 109.08 & 5 & 5.26 & 105.20 \\
$03 / 24 / 06$ & 10 & 10.78 & 107.80 & 4 & 3.98 & 99.47 & 5 & 5.28 & 105.60 \\
$03 / 27 / 06$ & 5 & 5.60 & 112.00 & 2 & 2.27 & 113.27 & 2 & 2.07 & 103.50 \\
$03 / 28 / 06$ & 5 & 5.50 & 110.04 & 2 & 2.27 & 113.31 & 2 & 2.17 & 108.50 \\
$04 / 18 / 06$ & 5 & 4.84 & 96.88 & 2 & 1.89 & 94.26 & 5 & 4.63 & 92.50 \\
$04 / 19 / 06$ & 2 & 2.05 & 102.55 & 2 & 1.78 & 89.17 & 1 & 0.95 & 94.95 \\
$04 / 20 / 06$ & 1 & 1.25 & 125.37 & 1 & 1.23 & 123.11 & 1 & 1.11 & 111.00 \\
$04 / 21 / 06$ & 2 & 2.48 & 123.90 & 2 & 2.21 & 110.57 & 2 & 2.20 & 110.00 \\
$04 / 24 / 06$ & 1 & 1.22 & 122.29 & 1 & 1.25 & 125.01 & 1 & 1.12 & 111.50 \\
$05 / 31 / 06$ & 1 & 1.15 & 114.66 & 1 & 1.28 & 128.13 & 1 & 1.07 & 107.00 \\
$05 / 31 / 06$ & 1 & 0.97 & 97.10 & & & & & & \\
$05 / 31 / 06$ & 1 & 1.01 & 101.36 & & & & & & \\
$06 / 06 / 06$ & 5 & 5.31 & 106.26 & 2 & 2.19 & 109.40 & 5 & 5.16 & 103.20 \\
$06 / 07 / 06$ & 10 & 10.71 & 107.10 & 1 & 1.07 & 107.40 & 5 & 5.31 & 106.10 \\
$06 / 08 / 06$ & 1 & 1.11 & 110.88 & 1 & 0.55 & 110.18 & 0.1 & 0.10 & 102.00 \\
$06 / 09 / 06$ & 0.5 & 0.48 & 96.32 & 0.2 & 0.22 & 110.95 & 0.3 & 0.31 & 103.33 \\
$06 / 10 / 06$ & 1.0 & 1.10 & 109.55 & 0.5 & 0.54 & 107.38 & 1.0 & 1.09 & 109.00 \\
\hline Average & \multicolumn{3}{|c|}{$108.86 \pm 8.44$} & \multicolumn{3}{c|}{$109.91 \pm 9.67$} & & $104.98 \pm 5.76$ \\
\hline
\end{tabular}

* Shaded areas are those samples outside the acceptable range.

Table 16. Summary of Laboratory Spikes

\begin{tabular}{lcc}
\hline Solution & $\begin{array}{c}\text { Spike, } \\
\text { ppm }\end{array}$ & Avg. Results, ppm \\
\hline $\mathrm{KCl}$ & 1 & $1.07 \pm 0.05$ \\
$\mathrm{KCl}$ & 2 & $2.07 \pm 0.04$ \\
$\mathrm{KCl}$ & 5 & $5.39 \pm 0.35$ \\
$\mathrm{KCl}$ & 10 & $10.56 \pm 0.6$ \\
$\mathrm{H}_{2} \mathrm{O}_{2}$ & 1 & $1.10 \pm 0.116$ \\
$\mathrm{H}_{2} \mathrm{O}_{2}$ & 2 & $2.14 \pm 0.196$ \\
$\mathrm{KMnO}_{4}$ & 1 & $0.92 \pm 0.063$ \\
$\mathrm{KMnO}_{4}$ & 5 & $4.99 \pm 0.515$ \\
$\mathrm{QC} \mathrm{Standard}_{\text {Check Standard }}$ & 4 & $4.03 \pm 0.12$ \\
\hline
\end{tabular}

analyzing these samples, including analyzing both blank and spiked samples. The results of the QA/QC completed by FGS are provided in the appendix.

The QA/QC check standard results for the samples analyzed using the Ohio Lumex are shown in Tables 17 and 18. As can be seen, the standard recoveries were excellent, and the field blank results were at or near the instrument detection limits. 
Table 17. Calibration Standard Recoveries for the Ohio Lumex

\begin{tabular}{lcc|ccc|ccc}
\hline $\begin{array}{l}\text { Standard, } \\
\text { ng }\end{array}$ & $\begin{array}{c}\text { Measured, } \\
\text { ng }\end{array}$ & $\begin{array}{c}\text { Recovery, } \\
\%\end{array}$ & $\begin{array}{c}\text { Standard, } \\
\text { ng }\end{array}$ & $\begin{array}{c}\text { Measured, } \\
\text { ng }\end{array}$ & $\begin{array}{c}\text { Recovery, } \\
\%\end{array}$ & $\begin{array}{c}\text { Standard, } \\
\text { ng }\end{array}$ & $\begin{array}{c}\text { Measured, } \\
\text { ng }\end{array}$ & $\begin{array}{c}\text { Recovery, } \\
\%\end{array}$ \\
\hline 500 & 482 & 96.4 & 100 & 102 & 102.0 & 25 & 27 & 108.0 \\
500 & 502 & 100.4 & 100 & 94 & 94.0 & 25 & 25 & 100.0 \\
300 & 290 & 96.7 & 100 & 102 & 102.0 & 25 & 23 & 92.0 \\
300 & 291 & 97.0 & 100 & 104 & 104.0 & 25 & 25 & 100.0 \\
300 & 293 & 97.7 & 100 & 109 & 109.0 & 20 & 19 & 95.0 \\
300 & 278 & 92.7 & 100 & 102 & 102.0 & 10 & 9.3 & 93.0 \\
300 & 318 & 106.0 & 100 & 103 & 103.0 & 10 & 9.8 & 98.0 \\
300 & 310 & 103.3 & 100 & 102 & 102.0 & 10 & 9.8 & 98.0 \\
300 & 317 & 105.7 & 50 & 43 & 86.0 & 10 & 9.4 & 94.0 \\
300 & 316 & 105.3 & 50 & 49 & 98.0 & 10 & 9.1 & 91.0 \\
300 & 321 & 107.0 & 50 & 52 & 104.0 & 10 & 12 & 120.0 \\
300 & 304 & 101.3 & 50 & 49 & 98.0 & 10 & 9.6 & 96.0 \\
300 & 293 & 97.7 & 50 & 42 & 84.0 & 10 & 9.6 & 96.0 \\
300 & 307 & 102.3 & 50 & 43 & 86.0 & 10 & 9.8 & 98.0 \\
300 & 309 & 103.0 & 50 & 51 & 102.0 & 5 & 5.1 & 102.0 \\
300 & 333 & 111.0 & 50 & 53 & 106.0 & 5 & 5.1 & 102.0 \\
300 & 321 & 107.0 & 50 & 45 & 90.0 & 5 & 4.9 & 98.0 \\
300 & 296 & 98.7 & 50 & 45 & 90.0 & 5 & 6.4 & 128.0 \\
150 & 157 & 104.7 & & & & 5 & 5.5 & 110.0 \\
\hline
\end{tabular}

Table 18. Sorbent Trap Field Blanks Using the Ohio Lumex

\begin{tabular}{lcrrc}
\hline Day & Trap 1, ng & Plug 1, ng & Trap 2, ng & Plug 2, ng \\
\hline 1 & -0.3 & 0.1 & 0.1 & 0.2 \\
2 & -0.1 & -0.5 & -0.4 & 0.3 \\
3 & -0.1 & 0.1 & 0.5 & 0.1 \\
4 & -0.5 & 0.4 & -0.1 & 0.0 \\
5 & -0.3 & 0.1 & 0.0 & 0.1 \\
6 & -0.4 & -0.2 & -0.6 & -0.3 \\
7 & -0.2 & -0.1 & 0.2 & 0.3 \\
8 & -0.5 & -0.4 & 0.1 & -0.2 \\
9 & 0.1 & -0.1 & -0.2 & -0.1 \\
10 & 0.5 & 0.1 & 0.0 & 0.6 \\
11 & 0.6 & -0.4 & 0.8 & 0.4 \\
12 & -0.2 & 1.5 & 1.5 & 1.5 \\
13 & -0.4 & -0.2 & -0.1 & -0.4 \\
\hline
\end{tabular}

\subsection{CONCLUSIONS AND RECOMMENDATIONS}

Although it should be remembered that the testing was completed at only one plant burning one coal, based on this test it appears that the two-section sorbent trap method can function as a reference method replacing the $\mathrm{OH}$ method. In fact, at low mercury concentrations, it appears to give more consistent results than the $\mathrm{OH}$ method. Also, within the statistical requirements of a RATA, the Ohio Lumex gave the same results as EPA Method 1631. Finally, 
it is clear that completing a RATA with the $\mathrm{OH}$ method is going to be a challenge. Using sorbent traps as a reference method would make this process much simpler. In fact, the sorbent trap sampling done at the Portland Station was done by relatively inexperienced personnel. Before the sorbent traps can be used in this manner, the method must be recognized by EPA as a valid reference method, and protocols must be established similar to the $\mathrm{OH}$ method. For this to happen, most likely similar tests will need to be completed at facilities burning other coals, including Texas and North Dakota lignites, Powder River Basin, and high-sulfur eastern bituminous coal.

As part of the reference methods protocols to be established for the sorbent traps, the analysis of the traps must be addressed. If, as a reference method, sorbent traps are to be as simple as possible and done in a timely manner for completing a RATA, EPA Method 1631 is not practical. A much better solution is that the traps be analyzed using the Ohio Lumex or similar instruments and to do these analyses on-site. For this to occur, QA/QC protocols must be established similar to those for EPA Method 1631.

\subsection{IRM METHOD TESTING}

As was listed in the objectives (Section 2), this project was designed to do preliminary IRM testing in conjunction with the $\mathrm{OH}$ and sorbent trap sampling. However, during the first test series, the oxidized mercury-spiking system was not yet ready for testing, and the instruments were not set up to do the required sampling. For the second test series, all the equipment needed to do the testing was available, but early in the test, we were required to stop testing. The project was set up to be piggybacked on the ALSTOM mercury control testing. The CMM to be used for this project was the same instrument being used for the ALSTOM test. It became clear early on that the IRM requirements essentially prevented ALSTOM from getting the data needed to evaluate ALSTOM'S mercury control technology. Therefore, the IRM testing was stopped. It was decided that, for the third test series, a separate instrument would be brought on-site and located at a completely different port. The results of the IRM testing are presented in this section.

\subsection{Equipment}

The instrument that was used for the test was a PS Analytical Sir Galahad CVAF system with a wet conversion system. The instrument has a 5-minute sample collection time. This instrument has been used extensively for field testing.

The most important aspect of IRM testing is to do dynamic spiking with both elemental and oxidized mercury. The oxidized mercury-spiking system to be used for the test was a system designed by the EERC. This system uses chlorine and a catalyst to convert $\mathrm{Hg}^{0}$ to $\mathrm{HgCl}_{2}$. A diagram of the system is shown in Figure 8 . Results have shown $\sim 95 \%$ conversion that held constant for a period of $140 \mathrm{hr}$. However, when this $\mathrm{HgCl}_{2}$-spiking system was used in an IRM testing regime, a problem occurred. IRM protocols require that both a high-and low-range span be used. As a result, it is necessary that different range mass flow controllers be used if the required IRM tolerances were to be obtained, and this was not possible for this test. Because the PS Analytical Sir Galahad system has a gold trap that collects the mercury prior to being 
analyzed, a direct manual spiking method was employed. A syringe was used to inject both elemental mercury and oxidized mercury directly into the sample line. The elemental mercury source was a Tekran elemental mercury calibration kit. The source of the oxidized mercury was a $100 \mathrm{ppb}$ mercury nitrate standard in a $10 \% \mathrm{HCl}$ solution. A long collection time was used to ensure that all of the spiked mercury was collected on the gold trap prior to desorption. A series of tests were performed using this spiking technique.

\subsection{Method Viability Tests}

These tests were conducted by sampling ambient air, first injecting elemental mercury, and then injecting the mercuric nitrate solution into the line just prior to the pretreatment/conversion system. The results are shown in Table 19. In general, the spike recovery was within $10 \%$ of the injection; therefore, the method was considered to be viable.

As a result of these tests, the CMM was configured such that IRM testing could be done. A schematic of the system is shown in Figure 9.

\subsection{IRM Testing}

As can be seen in Figure 9, the location of the spike port was in the line immediately following the probe. In this configuration, either dynamic or flooded spiking of the system can be done. The initial results sampling ambient air were very promising, as shown in Table 19 . Almost all the spike recoveries were within $10 \%$ of the actual spike. However, when dynamic

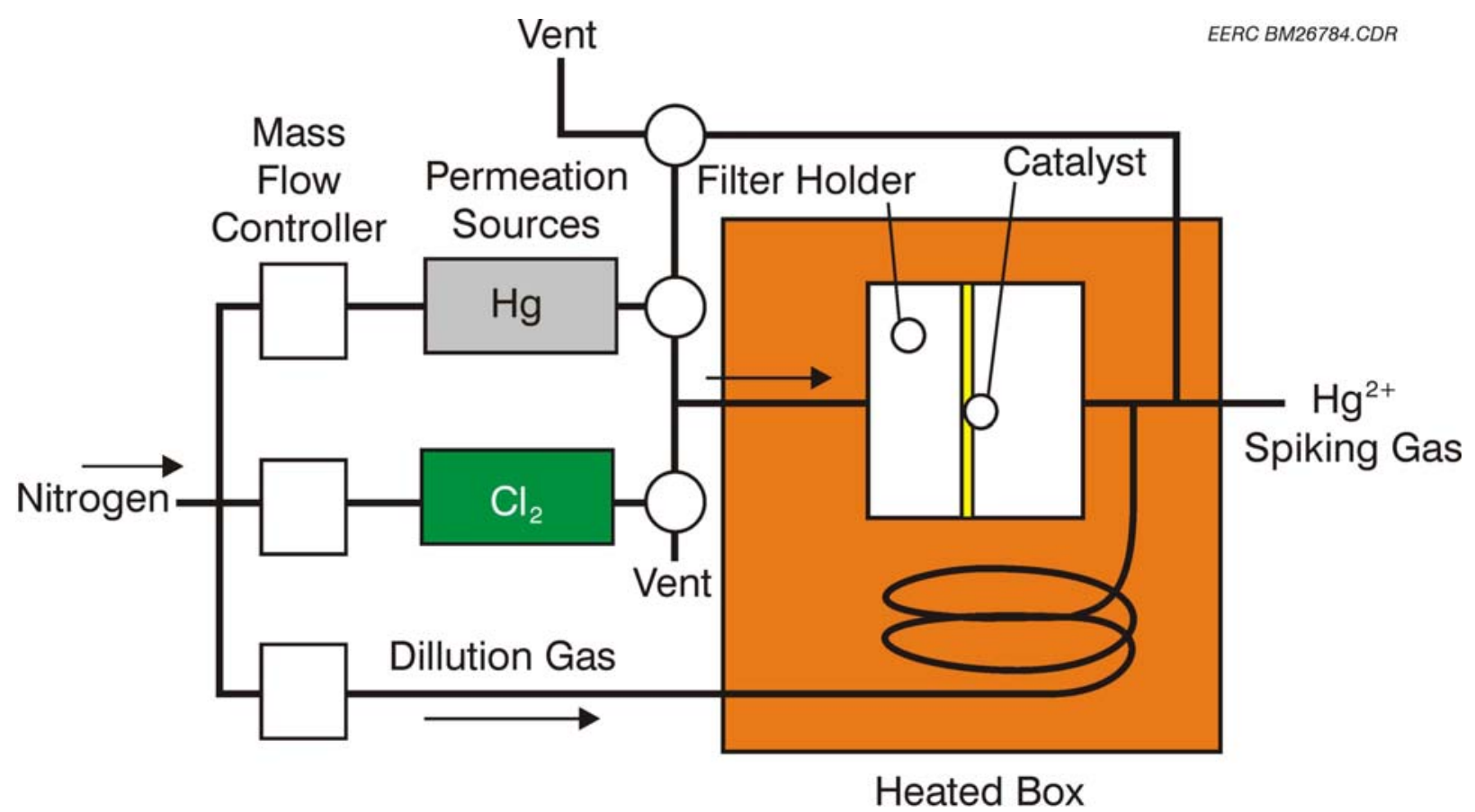

Figure 8. EERC oxidized mercury-spiking system. 


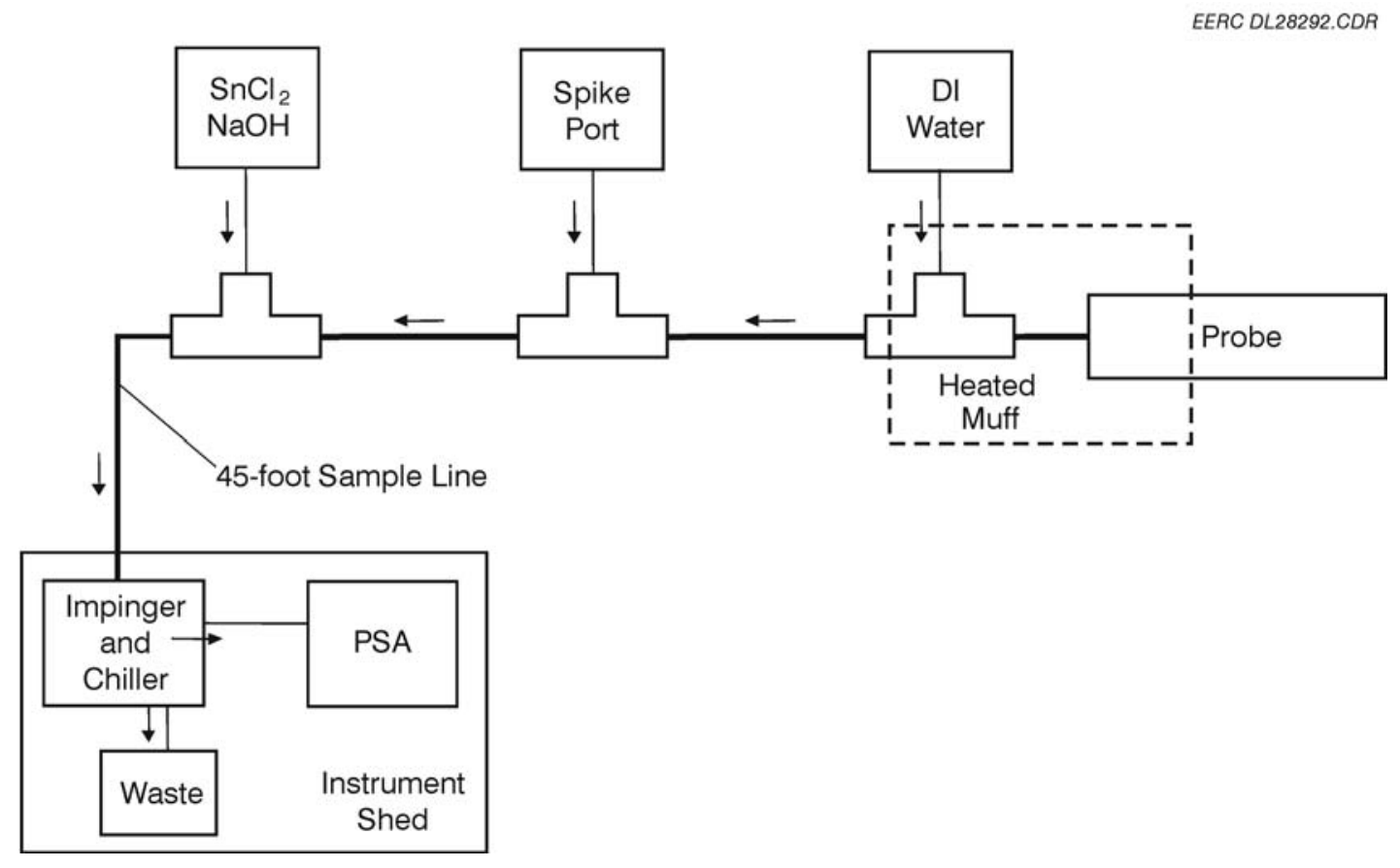

Figure 9. IRM testing configuration.

Table 19. IRM Spiking Viability Test (sampling ambient air)

\begin{tabular}{|c|c|c|c|c|c|}
\hline \multicolumn{3}{|c|}{$\begin{array}{c}\text { Element Mercury } \\
\text { CMM }\end{array}$} & \multicolumn{3}{|c|}{$\begin{array}{c}\text { Mercuric Nitrate } \\
\text { CMM }\end{array}$} \\
\hline $\begin{array}{l}\text { Injection, } \\
\mathrm{ng}\end{array}$ & $\begin{array}{l}\text { Reading, } \\
\text { ng }\end{array}$ & $\begin{array}{c}\text { Recovery, } \\
\%\end{array}$ & $\begin{array}{l}\text { Injection, } \\
\text { ng }\end{array}$ & $\begin{array}{c}\text { Reading, } \\
\text { ng }\end{array}$ & $\begin{array}{c}\text { Recovery, } \\
\%\end{array}$ \\
\hline 4.960 & 4.575 & 92.2 & 2.50 & 2.40 & 96.0 \\
\hline 4.960 & 4.365 & 88.0 & 2.50 & 2.20 & 88.0 \\
\hline 4.960 & 4.557 & 91.9 & 2.50 & 2.24 & 89.6 \\
\hline 4.960 & 4.364 & 88.0 & 5.00 & 4.63 & 92.6 \\
\hline 4.960 & 4.572 & 92.2 & 5.00 & 4.75 & 95.0 \\
\hline 1.488 & 1.431 & 96.2 & 1.25 & 1.20 & 96.0 \\
\hline 1.488 & 1.433 & 96.3 & 1.25 & 1.15 & 92.0 \\
\hline 1.488 & 1.372 & 92.2 & & & \\
\hline 1.488 & 1.450 & 97.4 & & & \\
\hline 2.646 & 2.447 & 92.5 & & & \\
\hline 2.646 & 2.512 & 94.9 & & & \\
\hline 2.646 & 2.396 & 90.6 & & & \\
\hline
\end{tabular}


spiking was used while sampling flue gas, the results were much more erratic, as shown in Tables 20 and 21. Following these tests, additional work was performed in an attempt to determine what was causing the erratic results. Tests were completed in an attempt to evaluate the following variables:

- Sample collection time

- Spike matrix effects

- Distance between chiller/gas-liquid separator and sample port

- Volume of sample gas

Table 20. IRM Configuration Tests (sampling ambient air)

\begin{tabular}{|c|c|c|c|c|c|}
\hline \multicolumn{3}{|c|}{$\begin{array}{c}\text { Element Mercury } \\
\text { CMM }\end{array}$} & \multicolumn{3}{|c|}{$\begin{array}{c}\text { Mercuric Nitrate } \\
\text { CMM }\end{array}$} \\
\hline $\begin{array}{l}\text { Injection, } \\
\text { ng }\end{array}$ & $\begin{array}{c}\text { Reading, } \\
\text { ng }\end{array}$ & $\begin{array}{c}\text { Recovery, } \\
\%\end{array}$ & $\begin{array}{c}\text { Injection, } \\
\text { ng }\end{array}$ & $\begin{array}{l}\text { Reading, } \\
\text { ng }\end{array}$ & $\begin{array}{c}\text { Recovery, } \\
\%\end{array}$ \\
\hline 5 & 4.12 & 82.4 & 2.5 & 2.60 & 104.0 \\
\hline 5 & 4.67 & 93.4 & 2.5 & 2.43 & 97.2 \\
\hline 5 & 4.67 & 93.4 & 2.5 & 2.51 & 100.4 \\
\hline 2.5 & 2.48 & 99.2 & 1.25 & 1.31 & 104.8 \\
\hline 2.5 & 2.56 & 102.4 & 1.25 & 1.29 & 103.2 \\
\hline 2.5 & 2.61 & 104.4 & 1.25 & 1.36 & 108.8 \\
\hline 1.25 & 1.42 & 113.6 & 5 & 4.69 & 93.8 \\
\hline 1.25 & 1.36 & 108.8 & 5 & 4.68 & 93.6 \\
\hline 1.25 & 1.48 & 118.4 & 5 & 5.26 & 105.2 \\
\hline 2.5 & 2.47 & 98.8 & 5 & 5.61 & 112.2 \\
\hline 2.5 & 2.39 & 95.6 & & & \\
\hline 2.5 & 2.35 & 94.0 & & & \\
\hline
\end{tabular}

\subsection{Conclusions}

No definitive results were obtained during the three days of testing. It may be that the wet pretreatment/conversion systems are more susceptible to mercury equilibrium changes than the dry systems. If this method is to be used, it is clear that additional testing is needed. However, the method may not be acceptable to EPA. Based on discussions with EPA, the uses of vapor pressure curves for elemental mercury are not considered National Institute of Standards and Technology standards.

\section{REFERENCES}

Not applicable. 
Table 21. Dynamic Spiking Results

\begin{tabular}{lccccc} 
Spike & $\begin{array}{c}\text { Injection, } \\
\text { ng }\end{array}$ & $\begin{array}{c}\text { Flue Gas } \\
\mathrm{Hg}, \mathrm{ng}\end{array}$ & $\begin{array}{c}\text { Actual } \\
\mathrm{Hg}, \mathrm{ng}\end{array}$ & $\begin{array}{c}\text { CMM } \\
\text { Reading, } \\
\text { ng }\end{array}$ & $\begin{array}{c}\text { Recovery, } \\
\%\end{array}$ \\
\hline $\mathrm{Hg}^{2+}$ & 10.83 & 2.6 & 13.43 & 9.25 & 68.9 \\
$\mathrm{Hg}^{2+}$ & 2.63 & 2.7 & 5.33 & 3.18 & 59.6 \\
$\mathrm{Hg}^{2+}$ & 2.71 & 2.6 & 5.31 & 5.98 & 112.6 \\
$\mathrm{Hg}^{2+}$ & 2.74 & 2.6 & 5.34 & 6.08 & 113.9 \\
$\mathrm{Hg}^{2+}$ & 2.70 & 2.5 & 5.20 & 6.92 & 133.1 \\
$\mathrm{HCl} \mathrm{Blank}^{2+}$ & 0.00 & 2.6 & 2.60 & 4.15 & 159.6 \\
$\mathrm{DI}$ Blank & 0.00 & 2.6 & 2.60 & 3.10 & 119.2 \\
$\mathrm{Hg}^{0}$ & 2.62 & 2.1 & 4.72 & 4.44 & 94.1 \\
\hline
\end{tabular}

